\title{
Nickel and its isotopes in organic- rich sediments: implications for oceanic budgets and a potential record of ancient seawater
}

\author{
Journal Article \\ Author(s): \\ Ciscato, Emily R.; Bontognali, Tomaso R.R.; Vance, Derek \\ Publication date: \\ 2018-07-15 \\ Permanent link: \\ https://doi.org/10.3929/ethz-b-000268588
}

Rights / license:

Creative Commons Attribution-NonCommercial-NoDerivatives 4.0 International

Originally published in:

Earth and Planetary Science Letters 494, https://doi.org/10.1016/j.epsl.2018.04.061

\section{Funding acknowledgement:}

143262 - The development and application of transition metal isotope systems in surface Earth geochemistry (SNF) 165904 - Metal isotope constraints on biosphere-environment interactions in Earth history (SNF) 


\title{
Nickel and its isotopes in organic-rich sediments: implications for oceanic budgets and a potential record of ancient seawater
}

\author{
Emily R. Ciscato ${ }^{a, *}$, Tomaso R. R. Bontognalia ${ }^{a, b}$, Derek Vance ${ }^{a}$ \\ ${ }^{a}$ Institute of Geochemistry and Petrology, Department of Earth Sciences, ETH Zürich, Clausiusstrasse \\ 25, 8092 Zürich, Switzerland \\ ${ }^{b}$ Space-X, Fbg de l'Hôpital 68, 2000 Neuchâtel, Switzerland
}

\begin{abstract}
Nickel (Ni) is a biologically active element that displays a nutrient-like depth distribution in the modern oceans. Recent studies of $\mathrm{Ni}$ isotopes have highlighted the fact that, in common with many other transition metals, the $\mathrm{Ni}$ stable isotope composition, expressed as $\delta^{60} \mathrm{Ni}$, of the dissolved phase is heavier than the inputs, at +1.3 to $+1.7 \%$. The sedimentary outputs that control the high $\delta^{60} \mathrm{Ni}$ of the ocean, coupled with records for past seawater, could potentially yield new information on the past Earth system, but these are currently not well understood. Here we present the first $\mathrm{Ni}$ abundance and isotope data for a key output, that associated with $\mathrm{Ni}$ uptake into organic matter, at productive upwelling regions and elsewhere. We investigate the distribution of $\mathrm{Ni}$ and its isotopes in two fractions separated from the bulk sediment, an HF-digestible fraction, extracted with $\mathrm{HF}-\mathrm{HCl}$, and an organic-sulphide-rich fraction. The organic-sulphide fractions exhibit a range in $\delta^{60} \mathrm{Ni}$, from +0.86 to +1.83 . Systematic relationships between $\mathrm{Ni}$ concentrations, total organic carbon and $\mathrm{Ni}$ isotopes suggest that the organic-sulphide fraction originates in the photic zone, and is delivered to the sediment as a closed system, despite the possibility of transfer of Ni to sulphide within it. Authigenic Ni in the bulk sediment is dominated by the HF-digestible fraction which, in Ni-enriched sediments where the detrital correction is small, is very close to the modern deep ocean, at $\delta^{60} \mathrm{Ni}=+1.2 \%$. These data
\end{abstract}

\footnotetext{
${ }^{*}$ Corresponding author, E-mail address: emily.ciscato@erdw.ethz.ch (E. R. Ciscato)
} 
suggest that organic-rich sediments beneath upwelling zones, while they are an important output flux of Ni from the oceans, do not solve the isotope balance problem because their $\delta^{60} \mathrm{Ni}$ is almost identical to modern seawater. On the other hand, the approach adopted here involving the analysis of the two fractions, both traces the fractionation imparted by biological uptake as well as recording the $\delta^{60} \mathrm{Ni}$ of contemporary seawater, suggesting potential for understanding the past oceans.

Keywords: Nickel, nickel isotopes, organic-rich sediment, authigenic enrichment, Peru margin, Lagoa Salgada 


\section{1. Introduction}

2 Nickel $(\mathrm{Ni})$ is a bioessential trace metal, characterized by a nutrient-type depth profile

3 in the modern ocean, with dissolved $\mathrm{Ni}$ concentrations reaching $11 \mathrm{nM}$ in the deep Pacific

4 and values as low as $2 \mathrm{nM}$ in many parts of the photic zone (e.g., Sclater et al., 1976;

5 Bruland, 1980; Mackey et al., 2002; Lai et al., 2008). The role of biological processes in

6 the oceanic cycling of $\mathrm{Ni}$ is confirmed by strong correlations between $\mathrm{Ni}$ concentrations

7 and those of the major nutrients like phosphate and silica (Sclater et al., 1976; Bruland,

8 1980). The specific biological roles of Ni have been reviewed by Ragsdale (2009). Nickel

9 is an essential component of at least seven enzymes involved in the biological cycling of

10 carbon, nitrogen, and sulphur. A further two are of key importance for the metabolism of

11 methanogens, which may have played a prominent role on the early Earth (e.g., Kasting,

12 2005; Konhauser et al., 2009).

13

14 In addition to its clear biological cycling, there are two other important processes that 15 control the marine geochemistry of Ni. First, like many other transition metals, sorption 16 to particulate Fe-Mn oxides represents an important output from the dissolved pool in 17 settings where oxygen is plentiful (e.g., Shaw et al., 1990; Peacock and Sherman, 2007;

18 Gall et al., 2013). On the other hand, Ni is also highly reactive towards dissolved sulphide 19 (e.g., Landing and Lewis, 1991). Thus, in the deep Black Sea sulphidation of dissolved $20 \mathrm{Ni}$, coupled to either scavenging of particle reactive sulphidised species or to sulphide 21 precipitation, also removes it from solution to sediment (e.g., Landing and Lewis, 1991; 22 Vance et al., 2016).

23

24 These aspects of the oceanic Ni cycle represent different outputs from the oceanic dis25 solved pool - uptake into cells and burial of organics, sorption to Fe-Mn oxides and sedi26 mentation under oxidising conditions, removal to particulate sulphide and sedimentation 27 under reducing conditions - whose relative importance now and in the past is controlled 28 by key aspects of the Earth's surface environment, including biological productivity and 
29 oceanic redox state. Previous work has highlighted the utility of metal isotope studies in 30 quantifying both the relative importance of these sinks in the modern ocean (e.g., Siebert 31 et al., 2003; Little et al., 2014; Andersen et al., 2014), and for understanding the environ32 mental drivers of fluctuations in these sinks throughout Earth history (e.g., Arnold et al., 33 2004; Pons et al., 2013). For nickel, isotope data published to date for the oceanic dis34 solved pool (Fig. 1, Cameron and Vance, 2014; Takano et al., 2017) show two key features.

35 Firstly, the $\delta^{60} \mathrm{Ni}$ (defined as $\left.\left[\left(\left({ }^{60} N i /{ }^{58} N i_{\text {sample }}\right) /\left({ }^{60} N i /{ }^{58} N i_{N I S T S R M 986}\right)\right)-1\right] * 1000\right)$ of 36 the water column is relatively homogeneous, though there is a subtle shift towards heavier $37 \mathrm{Ni}$ isotopes as $\mathrm{Ni}$ is drawn down in the photic zone (Archer et al., 2017; Takano et al., 38 2017). Secondly, the nickel isotope composition of the dissolved pool is significantly heav39 ier than the main input, the dissolved load of rivers, itself heavier than the best estimate 40 of the upper continental crust (UCC; Cameron and Vance, 2014; Gueguen et al., 2013). 41 This latter feature is common to a number of transition metals (e.g., Arnold et al., 2004; 42 Little et al., 2014), and requires that: (a) the oceans are not in steady-state for Ni and 43 its isotopes; (b) there is an uncharacterized heavy input that dominates over rivers or; (c) 44 that the outputs from the dissolved pool are isotopically light.

45

46 The first two potential explanations remain possible, though evidence has been pre47 viously marshaled against them (Gall et al., 2013; Cameron and Vance, 2014; Gueguen 48 et al., 2016), and we return to this issue in the discussion in the light of new data presented 49 in this study. Here, we focus on the third possible explanation for the apparent imbalance 50 in the marine isotope budget of Ni. Two outputs from the dissolved pool have been char51 acterized for $\mathrm{Ni}$ isotopes. The first is that associated with particulate Fe-Mn oxides (Gall 52 et al., 2013; Gueguen et al., 2016), whose surface layers cluster between $\delta^{60} \mathrm{Ni}=+1.6$ and $53+1.9$, with most $(\mathrm{n}=22$ out of 26$)$ heavier than the modern water column. This finding 54 thus worsens the isotopic mass balance problem (Fig. 1). Secondly, isotopically light Ni 55 is preferentially removed to sediment in sulphidic basins like the Black Sea (Vance et al., 56 2016). This finding is consistent with the reactivity of Ni towards dissolved sulphide (e.g., 57 Landing and Lewis, 1991), the fact that such aqueous sulphide species are particle reactive 
58 (or perhaps precipitated as sulphide minerals), and that aqueous sulphide species prefer

59 the light isotopes of Ni (Fujii et al., 2014).

60

61 Extraction of light $\mathrm{Ni}$ from seawater in euxinic water columns is important to the 62 oceanic isotope budget, but this output is almost certainly insufficient to quantitatively 63 solve the balance problem. Here, we quantify a sink that has not yet been characterised 64 for $\mathrm{Ni}$ isotopes, but that is well known to be a major output flux of $\mathrm{Ni}$ from the dissolved 65 pool of the oceans (Böning et al., 2015) - that associated with cellular uptake in the photic 66 zone and enhanced organic matter preservation beneath productive upwelling zones. In 67 addition, we investigate the degree to which the contemporary seawater signal can be ex68 tracted from organic matter in sediments, not only in the organic-rich sediments deposited 69 beneath productive upwelling zones, but also in organic-lean sediments such as carbonate.

70 In contrast to traditional bulk sediment digests, we measure Ni abundance and isotope 71 composition in an HF-dissolvable fraction and an "organic matter plus pyrite" fraction, 72 with the aim of learning more about the location and isotope composition of different 73 isotopic pools of $\mathrm{Ni}$ within sediments.

\section{2. Setting}

\section{2.1. Peru Margin}

76 The Peru Margin was chosen as the principal focus for this study, as it offers the op77 portunity to investigate organic-rich sediments deposited at sites with a range of bottom78 water oxygen $\left(\mathrm{O}_{2}\right)$ concentrations, and thus different sedimentary redox states. The Peru79 Chile margin is considered as the most productive upwelling system in the world ocean 80 (Fuenzalida et al., 2009). The high productivity of this region results in the permanent 81 eastern South Pacific oxygen minimum zone (OMZ), which has its core located between 825 and $13^{\circ} \mathrm{S}$. The seafloor below the OMZ and along the margin is dominated by two main 83 sedimentary facies: (i) a lens-shaped, up to 100m thick, diatomaceous (opal up to 16 84 wt.\%), organic-rich mud at depths between 50 and $500 \mathrm{~m}$ at $11-14^{\circ} \mathrm{S}$; and (ii) a coarser85 grained, less organic-rich, calcareous mud on the shallow shelf at $8.5^{\circ} \mathrm{S}$ and $15-17^{\circ} \mathrm{S}$ (Suess 
86 et al., 1987). Thus, the most organic-rich sediments are deposited between 11 and $14^{\circ} \mathrm{S}$,

87 which are the latitudes targeted here.

88

89 Peru Margin sediment cores were recovered as box cores and multicores in October-

90 November 1992 during a cruise of $R / V$ Seward Johnson, and as multicores in October-

91 November 2005 during cruise $182-9$ of $R / V$ Knorr. Upon recovery, all cores were immedi-

92 ately sliced at $0.5-1.0 \mathrm{~cm}$ intervals, stored in glass jars or plastic sampling bags, and frozen.

93 In this study we focused on core-tops recovered by $R / V$ Seward Johnson and multiple

94 down-core samples from three of the cores recovered by $R / V \operatorname{Knorr}$ (Fig. 2a,b), in order

95 to cover a range of redox conditions and organic matter contents. Following Böning et al.

96 (2004), the samples can be subdivided into three groups based on their location with

97 respect to the OMZ (see Supplementary Information for precise locations): (i) upper edge

98 of the $\mathrm{OMZ}$, where $\mathrm{O}_{2}$ is recorded to be $<10 \mu \mathrm{M}$ but may fluctuate to higher values during

99 El Niño years; (ii) lower shelf and upper slope, within the OMZ where $\mathrm{O}_{2}$ is at or below

$1005 \mu \mathrm{M}$; (iii) lower continental slope, below the OMZ.

\section{2.2. Lagoa Salgada}

102 The Lagoa Salgada site was chosen to investigate whether its carbonate-rich (34-75\%)

103 sediments, although only moderately organic-rich, also offer the possibility for isolating

104 an authigenic fraction. Lagoa Salgada is a coastal lagoon located south of the mouth

105 of Rio Paraíbo do Sul, in the south-east of Brazil (Fig. 2a,c), connected to the Atlantic

106 Ocean via the tidal channel Rio Acu (Bovier, 2015). Water depth and salinity are variable

107 depending on the season; the maximum depth, however, is mostly $<1 \mathrm{~m}$. The sediments

108 are carbonate-rich, with minor pyrite (Bovier, 2015).

109

110 Sampling took place in July 2014, when a sediment core was taken from the south111 western shore of the lagoon by immersion in the sediment of a polyvinyl chloride (PVC) 112 tube. The core was then sampled at $1.0 \mathrm{~cm}$ intervals and frozen. 


\section{Methods}

114 Much of the analytical methodology used in this study has been documented before 115 (Cameron et al., 2009; Cameron and Vance, 2014; Vance et al., 2016). The details are 116 recapitulated in the Supplementary Information, with only a brief summary given here. 117 However, the two-step digestion approach we use here is new. This is described in more 118 detail in section 3.1 below, and further relevant data are also presented in the Supple119 mentary Information.

120

121 One of our aims here was to investigate the location and isotope composition of $\mathrm{Ni}$ in 122 different fractions of organic-rich sediment, specifically those in an HF-digestible fraction 123 versus a residual organic matter-rich fraction. Our approach was inspired by previous 124 studies aimed at extracting kerogen from ancient organic-rich samples for carbon isotope 125 analysis (Eigenbrode and Freeman, 2006). Around 1g of bulk sediment was subjected to 126 a $\mathrm{HF}-\mathrm{HCl}$ digestion for $24 \mathrm{hr}$ followed by two steps involving $24 \mathrm{hr}$ reflux with $7 \mathrm{M} \mathrm{HCl}$, 127 evaporating to dryness between each step. Following re-dissolution in $7 \mathrm{M} \mathrm{HCl}$, the result128 ing HF-dissolvable fraction (HFD) and the residual solid (organic matter and associated 129 pyrite, OPF) were separated by centrifugation and decanting of the supernatant solution. 130 The residual OPF was brought into clear solution via high-pressure ashing (HPA-S by 131 Anton Paar) in a 10:1 mixture by volume of $13 \mathrm{M} \mathrm{HNO}_{3}$ and $10 \mathrm{M} \mathrm{HCl}$. Tests we describe 132 below and in the Supplementary Methods strongly suggest that small sulphide grains that 133 are intimately associated with organic matter are not significantly attacked by the initial $134 \mathrm{HF}-\mathrm{HCl}$ treatment. We are not able to be sure, at this stage, whether $\mathrm{Ni}$ from larger 135 sulphide grains that may be present in the samples and that are not intimately-associated 136 with organic matter, is mobilised by the HF-HCl fraction.

137

138 All OPF and HFD fractions were analyzed for elemental abundances on a ThermoSci139 entific Element $\mathrm{XR}^{\mathrm{TM}}$ inductively-coupled plasma mass spectrometer (ICP-MS) at ETH 140 Zürich. Nickel was then separated from the matrix by column chromatography following 
141 the addition of a double spike for the monitoring of mass bias. The total Ni blank for this 142 procedure was 3ng, dominated by the DMG column. A blank correction was applied to all 143 samples assuming a $\delta^{60} \mathrm{Ni}$ for the blank of 0 . For all except one sample, the resulting shift 144 is no greater than analytical uncertainty (for LS30 OPF $\delta^{60} \mathrm{Ni}$ is shifted upwards by 0.15 145 relative to that with no blank correction). Nickel isotopic compositions were measured on 146 a ThermoFinnigan NeptunePlus multicollector ICPMS at ETH Zürich, and are reported 147 relative to the NIST SRM986 standard, according to the following notation: 148

$$
\delta^{60} N i=\left[\frac{{ }^{60} N i /{ }^{58} N i_{\text {sample }}}{{ }^{60} N i /{ }^{58} N i_{\text {NISTSRM } 986}}-1\right] * 1000
$$

149

150 The long-term external reproducibility was determined by repeat measurements of two

151 secondary standards, USGS NodA1 and Nod P1. Analyses performed during the pe152 riod when the data presented here were obtained yielded $\delta^{60} \mathrm{Ni}=1.04 \pm 0.07 \%$ o $(\mathrm{n}=120)$ 153 and $\delta^{60} \mathrm{Ni}=0.34 \pm 0.08 \%(\mathrm{n}=99)$, respectively. In all tables and diagrams, these repro154 ducibilities are taken to be the real uncertainties unless, as in rare cases when analytical 155 signals were small, the internal uncertainty was greater, in which case the latter is used. 156

157 Freeze-dried bulk sediment samples and the extracted OPF were also analyzed for 158 total organic carbon (TOC) and $\delta^{13} \mathrm{C}$. Details are also provided in the Supplementary 159 Information. Isotope ratios are reported in the conventional notation with respect to the 160 V-PDB (Vienna Pee Dee Belemnite) standard:

161

$$
\delta^{13} C=\left[\frac{{ }^{13} C /{ }^{12} C_{\text {sample }}}{{ }^{13} C /{ }^{12} C_{V-P D B}}-1\right] * 1000
$$


164

165

166

167

168

169

170

171 narrow array, with the solid line on Figure 3 implying $90 \%$ retention of the organic carbon

172 in the $\mathrm{OPF}$ after the $\mathrm{HF}$ digestion. We also measured $\delta^{13} \mathrm{C}$ in selected bulk samples for

173 the Peru Margin as well as the OPF (Table 1), in order to test for any isotope fraction-

174 ation during the $\mathrm{HF}-\mathrm{HCl}$ digestion. The two datasets show the same range: -22.2 to

$175-20.2$ in the bulk sample versus -22.2 to -20.3 in the OPF. For individual samples, the

176 two measurements are in most cases analytically identical, with the maximum difference

177 between the two being $1.2 \%$.

178

179

180

181

182

183 stantial Ni. There are several potential issues: (1) is the OPF fraction contaminated by

184 un-digested silicate material, such as clays; (2) is Ni preferentially extracted from the

185 OPF relative to, e.g., carbon; (3) is there isotope fractionation of $\mathrm{Ni}$ associated with such

186 removal? There are small amounts of Al (Table 1) and other elements (see Supplementary

187 Information) associated with the OPF, but element ratios do not correspond to those of

188 clay minerals and XRD analysis demonstrates that the $\mathrm{Al}$ in the $\mathrm{OPF}$, and other elements

189 like $\mathrm{Na}$, is rather associated with residual fluoride salts (see Supplementary Information).

190 We investigated the potential issue of preferential leaching of $\mathrm{Ni}$, or its isotopes, using

191 three subsamples of a Peru Margin core-top. The different subsamples were subjected to

192 either one, two, or three separate HF treatments, all of which were analyzed, and after 
193 which the residual OPF fraction was ashed and analyzed. The results are presented in 194 detail in the Supplementary Information but to summarize here: (1) the amount of Ni 195 extracted by a second or third HF treatment is $\leq 10 \%$ that of the first treatment; (2) the $196 \delta^{60} \mathrm{Ni}$ of the resultant HFD fractions are within analytical uncertainty of each other; (3) 197 the Ni concentrations in the OPF after one, two, or three HF treatments are analytically 198 identical and; (4) the $\delta^{60} \mathrm{Ni}$ of the different OPF fractions are within analytical uncer199 tainty of each other.

200

201 Though we acknowledge that our attempt to separate the HF-digestible Ni fraction 202 from that in organic material cannot be shown to be perfect, we suggest that these tests 203 constitute strong evidence that it was for the most part successful. We further address 204 the degree to which the OPF remains a relatively closed system, not only during digestion

205 but also in the water column and sediment after $\mathrm{Ni}$ is first taken up by organic matter, 206 in section 5.1.

\section{4. Results}

208

209

210 within the range reported by previous studies for sediments from the same area (Böning 211 et al., 2004). As previously suggested by Böning et al. (2004), the systematic increase in 212 TOC contents from sites beneath the OMZ to those deposited within it (Table 1) probably 213 results mainly from a combination of enhanced organic matter preservation in more $\mathrm{O}_{2^{-}}$ 214 limited settings, but also from reduced supply of organic matter in deeper settings, and 215 different extents of its poleward transport by the undercurrent. Carbon isotope analyses 216 of the extracted OPF fractions yield a narrow range of $\delta^{13} \mathrm{C}$ : -20.3 to $-22.2 \%$ (Table 1 ). 217 These values are indicative of organic matter that is predominantly of marine origin, in 218 agreement with previous studies from this specific area (e.g., Calvert and Price, 1983). 
4.1.1. Ni concentrations and isotopic composition of modern organic-rich sediments

Ni concentrations and isotopic compositions for the bulk (Fig. 4a) and the individual HFD and OPF fractions (Fig. 4b) are presented in Table 1. Overall, the abundance of $\mathrm{Ni}$ in the bulk samples follows the same general pattern as that reported by Böning et al. (2004), who observe that $\mathrm{Ni}$ is most abundant in samples collected from within the OMZ, while lower concentrations are found in samples from the upper edge and below the OMZ. $\mathrm{Ni}$ in bulk samples is 18-139 ppm, with the respective HFD fractions containing 17-113 ppm and the OPF fractions 0.8-26 ppm. For all samples, most of the $\mathrm{Ni}$ is in the HFD fraction (70-96\%). There is no systematic change in Ni concentrations down core, in either the two fractions or in the bulk samples. The lowest Ni concentrations are always observed in samples from the most oxic setting, core MC9G (bulk: 18 - 22 ppm, HFD: 17 -

$19 \mathrm{ppm}, \mathrm{OPF}$ : $0.8-2.7 \mathrm{ppm}$ ), whereas $\mathrm{Ni}$ is most abundant in core MC11C, from within the OMZ (bulk: 82 -139 ppm, HFD: 66-113 ppm, OPF: 16-26 ppm). Core MC6A, as well as the core-tops from the upper OMZ and below the OMZ, lie between these, with Ni concentrations of 31-50 ppm for the bulk, 25-42 ppm for the HFD, and 5.6-15 ppm for the OPF. The cores are also significantly different in terms of the percentage of total Ni contained in the HFD fraction: $70-80 \%$ for core MC6A versus $80-83 \%$ for core MC11C and $87-96 \%$ for core MC9G.

The bulk $\delta^{60} \mathrm{Ni}$ for all samples lies in the range +0.94 to +1.33 , close to or below the average $\delta^{60} \mathrm{Ni}$ of the modern deep ocean (Fig. 4a). The OPF fractions exhibit the greatest isotopic variation, between +0.86 and +1.83 , with the heaviest values observed in samples from core MC6A and the lightest in samples from core MC11C (Fig. 4b). The HFD fractions have $\delta^{60} \mathrm{Ni}$ compositions between +0.86 and +1.37 , hence also close to or below the average value for the modern deep ocean $\delta^{60} \mathrm{Ni}$ (Fig. 4b). 
246 The TOC content of Lagoa Salgada sediments is mostly homogeneous below $20 \mathrm{~cm}$ 247 down-core (between 2.1 and 3.4 wt.\%). Carbon isotopes show a larger range than for 248 Peru (-7.0 to -23.5$)$. This, and the fact that the $\delta^{13} \mathrm{C}_{\text {organic }}$ values reported here show 249 a relatively constant shift from $\delta^{13} \mathrm{C}_{\text {carbonate }}$ (Bovier, 2015) of $24.6 \pm 1.2 \%$, suggests a 250 reservoir effect affecting carbon isotopes in the lagoon.

251 252 253 254 255 Table 1). The $\delta^{60} \mathrm{Ni}$ of the calculated bulk sediment, and of the HFD, are +0.17 to $256+0.31 \%$, with the exception of one bulk sample from $15 \mathrm{~cm}$ sediment depth in the core 257 which is heavier at $+0.71 \%$ (Table 1 ). The extracted OPF fraction, on the other hand, 258 seems to record the $\delta^{60} \mathrm{Ni}$ of the modern average deep ocean, with the exception of two 259 samples, at 15 and $30 \mathrm{~cm}$ sediment depth, that are very slightly heavier (Table 1).

\section{5. Discussion}

\section{5.1. The source of Ni in Peru Margin organic-rich sediments}

262 Böning et al. (2015) have previously identified a single strong correlation (with a near 263 zero intercept) between measured [Ni] and TOC, for organic-rich sediments in upwelling 264 regions globally. They also noted that $\mathrm{Ni}$ in the surface layers $(0-2 \mathrm{~cm})$ was dominantly 265 associated with chlorins, the immediate degradation products of chlorophyll pigments. 266 Overall, these findings led Böning et al. (2015) to conclude that the dominant control on 267 Ni abundances in organic-rich sediments was the supply of organic matter photosynthe268 sised by diatoms. As highlighted in Figure 5a the data presented here for Peru Margin 269 sediments reproduce these findings of Böning et al. (2015). Down-core [Ni] and TOC 270 data, irrespective of the location of the core with respect to the OMZ, lie on the array 
271 defined by the Böning et al. (2015) dataset.

273 One important question that arises here is the extent to which the Ni content of phy274 toplankton cells, as measured in the photic zone, is quantitatively sufficient to explain 275 sedimentary Ni/TOC relationships. The slope of the array in Figure 5a is about $9^{*} 10^{-4}$ $276 \mathrm{~g} / \mathrm{g}$ or $180 \mu \mathrm{mol} / \mathrm{mol}$. By contrast, reported Ni/C ratios in diatom cells are $4-8 \mu \mathrm{mol} / \mathrm{mol}$ 277 (Twining et al., 2011, their Table 5 and equivalent to a $\mathrm{Ni} / \mathrm{P}$ ratio of $1.2 \mathrm{mmol} / \mathrm{mol}$ ), with $278 \mathrm{Ni}$ in diatoms distributed roughly equally between internal biomass and frustule (Twining 279 et al., 2012). Thus, at face value, only a few \% of the total Ni in Peru Margin sediments 280 can be explained by incorporation of $\mathrm{Ni}$ into diatom cells and the unmodified export of 281 these cells to the sediment.

283 As shown in Figure 5c, the data for the organic-pyrite fraction (OPF) also imply a 284 reasonably constant $\mathrm{Ni} / \mathrm{C}$ ratio for Peru Margin samples, with most of the data between 2852 and $4^{*} 10^{-4} \mathrm{~g} / \mathrm{g}$ or $40-80 \mu \mathrm{mol} / \mathrm{mol}$, equivalent to a $\mathrm{Ni} / \mathrm{P}$ ratio of $4-8 \mathrm{mmol} / \mathrm{mol}$ for a 286 Redfield $\mathrm{C} / \mathrm{P}$ ratio. Data for phosphorous in the $\mathrm{OPF}$, shown in Figure 5d, also suggest 287 a very constant $\mathrm{Ni} / \mathrm{P}$ ratio, with the exception of two outlying OMZ samples that are 288 anomalously enriched in $\mathrm{P}$. The $\mathrm{Ni} / \mathrm{P}$ ratio implied by this correlation is much greater, at 289 about $90 \mathrm{mmol} / \mathrm{mol}$. However, the $\mathrm{C} / \mathrm{P}$ implied by the $\mathrm{P}$ data is also much higher than 290 the Redfield ratio, most likely due to the preferential remineralization of $\mathrm{P}$ that is well291 known in organic-rich sediments (e.g., Ingall and Jahnke, 1994; Paytan and McLaughlin, 292 2007). These findings lead us to put forward a hypothesis, one that can potentially be 293 tested with isotope measurements: that the $\mathrm{Ni}$ in the organic-pyrite fraction we extract 294 from these sediments may represent a reservoir that is sequestered to cells in the photic 295 zone, and that is transferred in relatively unmodified form to Peru Margin sediment.

297 The $\mathrm{Ni} / \mathrm{P}$ in the $\mathrm{OPF}$ implied by the $\mathrm{Ni} / \mathrm{C}$ data and Redfield $\mathrm{C} / \mathrm{P}$ is greater than 298 that previously found for the organic matter in single diatom cells recovered from the 299 photic zone $(0.52 \pm 0.10$; Twining et al., 2012), but overlaps with the range for the bio- 
genic fraction of both mixed layer (0.54-3.6) and ODZ particulates (4.6-4.8) reported

301 in Ohnemus et al. (2016). Though these latter authors present compelling evidence for 302 the presence of prokaryotic organisms, as opposed to diatoms, associated with particulate 303 maxima just beneath the mixed layer, at $50-250 \mathrm{~m}$, there is a second potential explanation 304 of the metal/P data in sub-surface particulates. Secondary electron microscope images 305 (see Supplementary Information) of the OPF extracted from the samples studied here 306 demonstrate that they contain two intimately associated phases - organic matter and 307 very small sulphide grains. An alternative interpretation of the data in Ohnemus et al. 308 (2016) is that the metal/P ratios of the particulates recovered from $50-250 \mathrm{~m}$, with Ni/P 309 ratios up to 4.8, represent those associated with decaying diatom organic matter from 310 the mixed layer. In other words, it is possible that these particulates represent diatom 311 cells that have lost carbon and phosphorus due to respiration while retaining metals like $312 \mathrm{Ni}$, perhaps in sulphide grains. The suggestion that metals are sequestered in reducing 313 micro-environments around decaying organic matter has been made before for other met314 als (e.g., Cd, Zn; Janssen et al., 2014; Janssen and Cullen, 2015).

316 In either case - modified diatom organic matter from the mixed layer or modified 317 prokaryotic organic matter from the deeper part of the photic zone - the consistency in 318 relationships between $\mathrm{Ni}, \mathrm{P}$ and carbon found here could be taken to suggest that the $\mathrm{Ni}$ in 319 the OPF derives from the upper $250 \mathrm{~m}$ of the water column, with some loss of carbon and 320 phosphorus to respiration. The OPF fraction would then have to remain a pseudo-closed 321 system for $\mathrm{Ni}$ - through the water column, into the sediment, and during the extraction 322 process by which we isolated it here. This hypothesis has caveats too. For example, 323 only $17 \pm 6 \%$ (1SD) of the authigenic $\mathrm{Ni}$ (see corrections for detrital $\mathrm{Ni}$ in section 5.3) 324 in the bulk sediments analyzed here is contained in the OPF, with the remainder in the 325 HF-digestible fraction. This opens the difficult question of where the remaining $83 \%$ of 326 the Ni comes from. One possibility is that it derives from the Ni content of diatom opal. 327 However, given maximum diatom opal contents in these sediments of about 15\% (Böning 328 et al., 2004) and the Ni/Si ratio in diatom opal reported in Twining et al. (2012) of 28 
$329 \mu \mathrm{mol} / \mathrm{mol}$, only a small fraction of the $\mathrm{Ni}$ in these sediments, again only a few \%, can

330 be associated with opal. Even a pure opal sediment would not get close to explaining 331 the Ni inventory of the HF-digested fraction of the Peru sediments. Of course, it is well332 established that only a fraction of the diatom opal produced in the photic zone survives 333 transport through the water column (on average 10-15\%; Tréguer et al., 1995), and that 334 only a small portion of this survives dissolution within sediment (15-20\%; Tréguer et al., 335 1995; Ragueneau et al., 2002). Thus if, in a manner analogous to that suggested above 336 for the $\mathrm{OPF}, \mathrm{Ni}$ is retained on residual opal while the silica is lost to the water column, 337 then the delivery of diatom opal to these sediments can indeed explain the inventory we 338 find in the HFD fraction.

The above discussion illustrates the necessity for further studies of water column par341 ticulate material if we are to better understand the pathways by which metals are delivered 342 via export production from the photic zone to sediment, and if we are to robustly inter343 pret data for ancient sediments. But, any process additional to those discussed above is 344 required to preserve the strong relationship between sedimentary Ni contents and TOC. 345 Though speculation at present, a potential process is the diffusion of Ni into sediment, 346 driven by a concentration gradient in the dissolved phase as $\mathrm{Ni}$ is fixed into diagenetic 347 solid phases beneath the sediment-water interface - in a process analogous to that thought 348 to operate for uranium (e.g., Anderson, 1987; Andersen et al., 2014). In the succeeding 349 section we use the isotope data to shed further light on these questions.

\section{0} 351

\subsection{Nickel isotopes in the organic-pyrite fraction: a biogenic signal from} the upper ocean

The $\delta^{60} \mathrm{Ni}$ data for the organic-pyrite fraction (Fig. 4b) is mostly in the range +0.86 to +1.39 . As highlighted in Figures 6 and 7, the variability within this range comes with systematic relationships that suggest more specific links to water column processes. For example, most of the Peru Margin data in Figure 6 lie on an array that is consistent with Ni removal from a relatively homogeneous reservoir with a small isotope fractiona- 
357 tion $(-0.3 \%, \alpha=0.9997)$. These findings are consistent with the suggestion that the $\mathrm{Ni}$

358 in the OPF was taken up in the photic zone and that this signal has survived into the 359 sediment relatively unmodified. For example, published data for the photic zone imply 360 a fractionation factor associated with drawdown of 0.9997, and that upwelled deep wa361 ter is about $0.3-0.4 \%$ heavier than the value at the lower end of the array on Figure 3626 (Archer et al., 2017; Takano et al., 2017). Thus, many of the OPF data show sys363 tematics that are consistent with the hypothesis that this fraction represents a reservoir 364 of $\mathrm{Ni}$ that is relatively unmodified after uptake into cells in the photic zone. Data for 365 the core from below the Peru OMZ, as well as data for Lagoa Salgada also form an array 366 on Figure 6, but with a much lower slope, possibly related to a different microbial ecology.

368 The scatter on Figure 6 might be due to post-uptake processes, the harsh treatment in

369 the laboratory, but could also be due to biological processes. For example, two analyses 370 from core MC6A lie at very high $\delta^{60} \mathrm{Ni}$, and are above the array on Figure 6. As shown 371 in Figure 7, this variability in $\mathrm{Ni}$ isotopes may come with correlated variability in $\delta^{13} \mathrm{C}$ 372 - as do other aspects of the Ni isotope data from Peru and Lagoa Salgada. We cannot 373 speculate here on the specific meaning of these relationships but their existence provides 374 additional support for the suggestion that the Ni in the OPF, though there may be transfer 375 to sulphide grains within the OPF package, derives from the site of biomass production, 376 in this case probably the photic zone.

381 isotopic composition of that authigenic Ni in the bulk analysis a correction for the detrital $382 \mathrm{Ni}$ inventory must be made. The conventional approach to such corrections is to use the 383 concentration of $\mathrm{Al}$ or $\mathrm{Ti}$ as tracers of detrital input, as these elements are abundant in 384 silicate minerals and present at low abundance in seawater (e.g., Brumsack, 1989). Thus: 


$$
[N i]_{\text {authigenic }}=[N i]_{\text {bulk sample }}-[A l]_{\text {bulk sample }} *(N i / A l)_{\text {detrital }}
$$

386

387 Böning et al. (2012) use the intercept on a plot of $\mathrm{Ni} / \mathrm{Al}$ ratio versus TOC to define the $388 \mathrm{Ni} / \mathrm{Al}$ ratio of the detrital fraction. The Ni/Al versus TOC data presented here (Fig. 5b)

389 fall on arrays defining intercepts that range from slightly negative up to those found by 390 Böning et al. (2012) for Peru OMZ samples. Here we apply the full range suggested by 391 Böning et al. (2012) for upwelling regions, of $0-3 \cdot 3^{*} 10^{-4} \mathrm{~g} / \mathrm{g}$, and propagate the uncer392 tainty this range represents through to the final authigenic $\delta^{60} \mathrm{Ni}$.

393

394 Then the isotopic composition of the authigenic fraction is obtained from: 395

$$
\delta^{60} N i_{\text {authigenic }}=\frac{\delta^{60} N i_{\text {bulk }}-f_{\text {detrital }} \delta^{60} N i_{\text {detrital }}}{f_{\text {authigenic }}}
$$

396

397 where $\mathrm{f}_{\text {authigenic }}$ and $\mathrm{f}_{\text {detrital }}$ are the fractions of authigenic and detrital $\mathrm{Ni}$ in the sample, re398 spectively, and $\delta^{60} \mathrm{Ni}_{\text {bulk }}, \delta^{60} \mathrm{Ni}_{\text {detrital }}$, and $\delta^{60} \mathrm{Ni}_{\text {authigenic }}$ are the un-corrected bulk, detrital, 399 and authigenic $\mathrm{Ni}$ isotope compositions, respectively. A value for $\delta^{60} \mathrm{Ni}_{\text {detrital }}$ is required 400 to derive the authigenic $\mathrm{Ni}$ isotope composition, and is conventionally taken to be that 401 of the upper continental crust (UCC). Data for loess, river sediments, and basalts $(\mathrm{n}=15$, 402 Cameron et al., 2009) suggest a value of $+0.14 \pm 0.23$, which we use here. In Figure 8 403 the lower end of the vertical line for each sample represents no correction $\left(\mathrm{Ni} / \mathrm{Al}_{\text {detrital }}=\right.$ $4040)$ while the upper end represents a $\mathrm{Ni} / \mathrm{Al}_{\text {detrital }}=3.3$ and the lowest possible $\delta^{60} \mathrm{Ni}_{\text {detrital }}$ 405 given the data above, and thus the maximum possible corrected $\delta^{60} \mathrm{Ni}_{\text {authigenic }}$. The Lagoa 406 Salgada sediments are dominated by carbonate and their $\delta^{60} \mathrm{Ni}$ are close to the UCC. The $407 \mathrm{Ni} / \mathrm{Al}$ ratios of these sediments are also consistent with a lithogenic origin. 408

409 It is apparent from Figure 8 that the bulk $\delta^{60} \mathrm{Ni}_{\text {authigenic }}$ obtained in this way, given 410 the uncertainty in the correction introduced by that in the detrital $\mathrm{Ni} / \mathrm{Al}$ ratio, are all 
411 consistent with derivation from the water column dissolved pool. For un-corrected bulk $412 \mathrm{Ni} / \mathrm{Al}$ ratios below about $1^{*} 10^{-3} \mathrm{~g} / \mathrm{g}$, and for the conservative range of detrital $\mathrm{Ni} / \mathrm{Al}$ 413 ratios used here, the correction is potentially very large, the resultant $\delta^{60} \mathrm{Ni}_{\text {authigenic }}$ very 414 uncertain, and it seems clear that the maximum $\mathrm{Ni} / \mathrm{Al}_{\text {detrital }}$ ratio assumed here over415 corrects for detrital $\mathrm{Ni}$. For $\mathrm{Ni} / \mathrm{Al}$ ratios $>1 * 10^{-3} \mathrm{~g} / \mathrm{g}$ the correction for detrital $\mathrm{Ni}$ is 416 much smaller and $\delta^{60} \mathrm{Ni}_{\text {authigenic }}$ is much more precisely known. It is also significant that, 417 though recent data for the photic zone extend well above the deep ocean $\delta^{60} \mathrm{Ni}$ to $+1.7 \%$ 418 (Archer et al., 2017; Takano et al., 2017), none of the more robust $\delta^{60} \mathrm{Ni}_{\text {authigenic }}$ extend 419 above about $+1.3 \%$.

421 The suggestion that $\mathrm{Ni}$ in the HFD is not derived from the photic zone provides 422 tentative support for the idea of inward diffusion from bottom water. Whatever the precise 423 mechanism, it is clear that authigenic $\mathrm{Ni}$ in these sediments is derived from the water 424 column with very little isotopic modification. This conclusion is very robust for sediments 425 with bulk Ni/Al ratios $>1 * 10^{-3} \mathrm{~g} / \mathrm{g}$, and is also likely to be the case for sediments with $426 \mathrm{Ni} / \mathrm{Al}$ ratios beneath this cutoff.

\section{7} 428 429 430 431 432 433

434 For the main input fluxes discussed in Cameron and Vance (2014) there is little new 435 to add here. The dissolved load of rivers is a well-known input, and what is known about $436 \mathrm{Ni}$ behavior in the estuaries of large rivers does not suggest much deviation from con437 servative behavior (e.g., Boyle et al., 1982; Edmond et al., 1985). There is no evidence 438 for a significant hydrothermal flux of $\mathrm{Ni}$ to the oceans. Indeed, recent GEOTRACES 
439 sections (see Supplementary Information) suggest that hydrothermal plumes may be sites 440 of Ni removal by scavenging. The maximum Ni concentrations that have been reported 441 for hydrothermal fluids are from ultramafic substrates and reach $3 \mu \mathrm{M}$ (Douville et al., 442 2002). Even if all hydrothermal fluids had this high concentration, and if none of the Ni 443 in those fluids was removed close to the ridge by scavenging, this would imply a maximum 444 hydrothermal Ni flux of order $9^{*} 10^{7} \mathrm{~mol} / \mathrm{yr}$. This is about $25 \%$ of the modern riverine 445 flux of $\mathrm{Ni}$, and must be a very substantial overestimate. Wheat et al. (2002) also calculate 446 the flux of $\mathrm{Ni}$ from a warm ridge-flank hydrothermal system to be insignificant. In terms 447 of outputs, Vance et al. (2016) and the current study provide new data documenting the 448 output of $\mathrm{Ni}$ and its isotopes to anoxic and sulphidic sediments that have not yet been 449 considered in the oceanic mass balance. We can estimate the sizes of these two sinks given 450 the Ni/TOC ratio of the sediments and published estimates for the organic carbon burial 451 fluxes in these settings (e.g., Hedges and Keil, 1995), as is done in Table 2. Given the $452 \mathrm{Ni} /$ TOC ratio of Lagoa Salgada sediments of $1.4^{*} 10^{-4}$, and a global carbon burial flux 453 associated with carbonate sediments of $6^{*} 10^{12} \mathrm{~g} / \mathrm{yr}$, we also estimate a Ni burial flux to 454 carbonate sediments of $1.4^{*} 10^{7} \mathrm{~mol} / \mathrm{yr}$.

455

456 As discussed in Gall et al. (2013) and Cameron and Vance (2014), the final major 457 output of $\mathrm{Ni}$ from the oceans is likely to be sorption to and burial of particulate Fe-Mn 458 oxides. The size of this output has variously been estimated at $1.5^{*} 10^{9} \mathrm{~mol} / \mathrm{yr}$ (Cameron 459 and Vance, 2014) to $5.1^{*} 10^{8} \mathrm{~mol} / \mathrm{yr}$ (Gall et al., 2013). These estimates, however, present 460 a mass balance problem in that the size of the total quantified output they imply, taken 461 together with the data presented here, is 2-5 times the quantified input. At face value, the 462 above elemental imbalance suggests that there must be a large and as yet unquantified 463 input flux. One possibility is that the dissolved phase of rivers does not represent the 464 entire input to the oceans from this source, and that there is significant mobilization of $\mathrm{Ni}$ 465 from the particulate load, as has been suggested for other elements (e.g., Oelkers et al., 466 2012). A second possibility is that the large and poorly-constrained Fe-Mn output flux is 467 much smaller than the above estimates imply. 
469 The isotopic characteristics of the various inputs and outputs have an important bear470 ing on this mass balance problem. In general, the issue with the isotope mass balance is 471 that all the known inputs have an isotope composition that is lighter than seawater, while 472 the largest known outputs are either heavier than seawater (Gall et al., 2013) or very close 473 to it (this study). Isotope data appears to rule out potential issues with uncertainties in 474 the immediately obvious additional inputs. For example, though the labile portion of 475 riverine particulates can provide the missing input, early data for the isotope composition 476 of $\mathrm{Ni}$ in these phases suggests that it is no different from the upper continental crust 477 (Revels et al., 2017), and thus also lighter than seawater. A much bigger dust input than 478 previously imagined would have the same problem. As discussed earlier, the hydrothermal 479 flux of $\mathrm{Ni}$ to the oceans is almost certainly insignificant and, given the homogeneity of 480 the Ni isotope composition of the basalts from which they derive (Cameron et al., 2009; 481 Elliott and Steele, 2017), it would also come with the same problem.

483 We suggest that the solution to these budget problems may lie with diagenetic pro484 cesses that are likely to occur under both oxic and suboxic conditions, processes that may 485 drive an as yet un-quantified flux of Ni back out of sediments. Atkins et al. (2016) have 486 suggested that an additional benthic input to the ocean could result from the release of $\mathrm{Ni}$ 487 (up to about 50\%) to the water column upon transformation of birnessite to todorokite 488 in oxic settings. If such a back-flux were isotopically heavy this could solve both the 489 elemental and isotopic imbalances. Such a solution would, however, require that all the 490 Fe-Mn crusts measured thus far have not undergone this birnessite-todorokite transition 491 and that there must exist some Fe-Mn deposits that represent the final buried output from 492 the dissolved pool and that are not yet characterized. Shaw et al. (1990) present pore 493 water data that mobilization of $\mathrm{Ni}$ into pore water (with concentrations as high as 600 $494 \mathrm{nM}$ ) that is clearly coupled to the reductive dissolution of dispersed Mn-oxide coatings 495 in reducing sediments. In situations where the redox conditions at the sediment-water 496 interface remain in the Mn-reducing regime, Ni could leak back out of sediment and into 
497

498

499

500 501 502 503 504 505 506 507 508 509 510 511 512 from Fe-Mn oxides.

\section{6. Conclusions}

514 The twin objectives of this study were: (1) to understand and quantify an important 515 sedimentary sink for $\mathrm{Ni}$ isotopes, that into Ni-enriched sediments in productive upwelling 516 settings, and; (2) to investigate the degree to which a water column Ni isotope signature 517 can be extracted from sediments - both from the bulk sediment inventory and through 518 the isolation of different fractions. We find that an organic and sulphide rich residue (an 519 organic plus pyrite fraction - OPF), isolated from both organic-rich and carbonate sed520 iments after HF digestion, preserves $\delta^{60} \mathrm{Ni}$ that is close to the modern water column, at $521+1.3 \pm 0.4 \%$. The detailed Ni-TOC- $\delta^{60} \mathrm{Ni}-\delta^{13} \mathrm{C}$ characteristics of this fraction record pro522 cesses occurring at the site of biomass production and Ni uptake (e.g., photic zone), and 523 appears to remain a pseudo-closed system for $\mathrm{Ni}$ and its isotopes during transfer through 524 the water column and delivery to the sediment-water interface. For bulk samples from up- 
525 welling zones that are highly enriched in $\mathrm{Ni}\left(\mathrm{Ni} / \mathrm{Al}>10^{-3} \mathrm{~g} / \mathrm{g}\right)$, and where correction for

526 detrital $\mathrm{Ni}$ input is not significant, the HF-digestible fraction, which dominates the non-

527 detrital fraction of the bulk sediment, records the average $\delta^{60} \mathrm{Ni}$ of the modern deep ocean.

528

529 Although the upwelling margin sediments investigated here are an important sink for

$530 \mathrm{Ni}$ from the ocean, their $\delta^{60} \mathrm{Ni}$ is so close to that of modern seawater that they exert very

531 little isotopic leverage on the water column, and the heavy isotope composition of modern

532 water column Ni must have other drivers. The methodological approach presented here,

533 involving the isolation and analysis of different fractions of the bulk sediment, has the

534 potential to provide records of this water column isotope composition back through time,

535 as well as to quantify isotope fractionations associated with biological uptake in the past,

536 for $\mathrm{Ni}$ and perhaps for other transition metals too.

\section{Acknowledgments}

538 We wish to thank T. Eglinton, C. Vasconcelos, and C. Bovier for providing samples.

539 For help and support in the lab we greatly thank C. Archer, and M.Jaggi. We thank Shui-

540 Jiong Wang and an anonymous reviewer for their constructive comments on an earlier

541 version of this paper, and Louis Derry for editorial handling. This research was funded

542 by the Swiss National Science Fund (grants 200021_143262 and 200020_165904) and ETH

543 Zürich.

\section{References}

545 Andersen, M. B., Romaniello, S., Vance, D., Little, S. H., Herdman, R., Lyons, T. W., 546 2014. A modern framework for the interpretation of ${ }^{238} \mathrm{U} /{ }^{235} \mathrm{U}$ in studies of ancient 547 ocean redox. Earth and Planetary Science Letters 400, 184-194.

548 Anderson, R. F., 1987. Redox behavior of uranium in an anoxic marine basin. Uranium $5493,145-164$. 
550 Archer, C., Vance, D., Lohan, M. C., 2017. Negligible Ni Isotope Fractionation Associated 551 with Phytoplankton Uptake in the South Atlantic Ocean. Goldschmidt Abstarcts, 131. 552 URL https://goldschmidtabstracts.info/2017/131.pdf

553 Arnold, G. L., Anbar, A. D., Barling, J., Lyons, T. W., 2004. Molybdenum Isotope 554 Evidence for Widespread Anoxia in Mid-Proterozoic Oceans. Science 304, 87-90.

555 Atkins, A. L., Shaw, S., Peacock, C. L., 2016. Release of Ni from birnessite during trans556 formation of birnessite to todorokite: Implications for Ni cycling in marine sediments. 557 Geochimica et Cosmochimica Acta 189, 158-183.

558 Birgel, D., Meister, P., Lundberg, R., Horath, T. D., Bontognali, T. R. R., Bahniuk, 559 A. M., de Rezende, C. E., Vasconcelos, C., McKenzie, J. A., 2015. Methanogenesis 560 produces strong ${ }^{13} \mathrm{C}$ enrichment in stromatolites of Lagoa Salgada, Brazil: a modern 561 analogue for Palaeo-Neoproterozoic stromatolites? Geobiology 13, 245-266.

562 Böning, P., Brumsack, H.-J., Böttcher, M. E., Schnetger, B., Kriete, C., Kallmeyer, J., 563 Borchers, S. L., 2004. Geochemistry of Peruvian near-surface sediments. Geochimica et 564 Cosmochimica Acta 68, 4429-4451.

565 Böning, P., Fröllje, H., Beck, M., Schnetger, B., Brumsack, H.-J., 2012. Underestimation 566 of the authigenic fraction of $\mathrm{Cu}$ and $\mathrm{Ni}$ in organic-rich sediments. Marine Geology 323$567325,24-28$.

568 Böning, P., Shaw, T., Pahnke, K., Brumsack, H.-J., 2015. Nickel as indicator of fresh 569 organic matter in upwelling sediments. Geochimica et Cosmochimica Acta 162, 99-108.

570 Bovier, C., 2015. Sedimentological and geochemical studies on microbialite structures and 571 sediments from Lagoa Salgada, Rio de Janeiro, Brazil. Master Thesis ETH Z?rich.

572 Boyle, E. A., Huested, S. S., Grant, B., 1982. The chemical mass balance of the amazon 573 plume?II. Copper, nickel, and cadmium. Deep Sea Research Part A. Oceanographic $574 \quad$ Research Papers 29, 1355-1364. 
575 Bruland, K. W., 1980. Oceanographic distributions of cadmium, zinc, nickel, and copper 576 in the North Pacific. Earth and Planetary Science Letters 47, 176-198.

577 Bruland, K. W., Lohan, M. C., 2003. Controls of trace metals in seawater. Treaties on 578 Geochemistry 6, 23-47.

579 Brumsack, H. J., 1989. Geochemistry of recent TOC-rich sediments from the Gulf of 580 California and the Black Sea. Geologische Rundschau 78, 851-882.

581 Calvert, S. E., Price, N. B., 1983. Geochemistry of Namibian shelf sediments. In: Coastal 582 Upwelling Its Sediment Record. Springer, pp. 337-375.

583 Cameron, V., Vance, D., 2014. Heavy nickel isotope compositions in rivers and the oceans. 584 Geochimica et Cosmochimica Acta 128, 195-211.

585 Cameron, V., Vance, D., Archer, C., House, C. H., 2009. A biomarker based on the stable 586 isotopes of nickel. Proceedings of the National Academy of Sciences 106, 10944-10948.

587 Desboeufs, K., Sofikitis, A., Losno, R., Colin, J., Ausset, P., 2005. Dissolution and solubil588 ity of trace metals from natural and anthropogenic aerosol particulate matter. Chemo589 sphere 58, 195-203.

590 Douville, E., Charlou, J. L., Oelkers, E. H., Bienvenu, P., Jove Colon, C. F., Donval, 591 J. P., Fouquet, Y., Prieur, D., Appriou, P., 2002. The rainbow vent fluids $\left(36^{\circ} 14^{\prime} N\right.$, 592 MAR): the influence of ultramafic rocks and phase separation on trace metal content 593 in Mid-Atlantic Ridge hydrothermal fluids. Chemical Geology 184, 37-48.

594 Edmond, J. M., Spivack, A., Grant, B. C., Ming-Hui, H., Zexiam; Chen Sung; 595 Zeng Xiushau, C., 1985. Chemical dynamics of the Changjiang estuary. Continental 596 Shelf Research 4, 17-36.

597 Eigenbrode, J. L., Freeman, K. H., Oct. 2006. Late Archean rise of aerobic microbial 598 ecosystems. Proceedings of the National Academy of Sciences 103, 15759-15764. 
599 Elliott, T., Steele, R. C. J., 2017. The Isotope Geochemistry of Ni. Reviews in Mineralogy 600 and Geochemistry 82, 511-542.

601 Fuenzalida, R., Schneider, W., Garcés-Vargas, J., Bravo, L., Lange, C., 2009. Vertical and 602 horizontal extension of the oxygen minimum zone in the eastern South Pacific Ocean. 603 Deep Sea Research Part II: Topical Studies in Oceanography 56, 992-1003.

604 Fujii, T., Moynier, F., Blichert-Toft, J., Albaréde, F., 2014. Density functional theory 605 estimation of isotope fractionation of $\mathrm{Fe}, \mathrm{Ni}, \mathrm{Cu}$, and $\mathrm{Zn}$ among species relevant to 606 geochemical and biological environments. Geochimica et Cosmochimica Acta 140, 553607576.

608 Gall, L., Williams, H., Siebert, C., Halliday, A., Herrington, R., Hein, J., 2013. Nickel 609 isotopic compositions of ferromanganese crusts and the constancy of deep ocean inputs 610 and continental weathering effects over the Cenozoic. Earth and Planetary Science 611 Letters $375,148-155$.

612 Gueguen, B., Rouxel, O., Ponzevera, E., Bekker, A., Fouquet, Y., 2013. Nickel Isotope 613 Variations in Terrestrial Silicate Rocks and Geological Reference Materials Measured 614 by MC-ICP-MS. Geostand Geoanal Res 37, 297-317.

615 Gueguen, B., Rouxel, O., Rouget, M.-L., Bollinger, C., Ponzevera, E., Germain, Y., Fou616 quet, Y., Sep. 2016. Comparative geochemistry of four ferromanganese crusts from the 617 Pacific Ocean and significance for the use of $\mathrm{Ni}$ isotopes as paleoceanographic tracers. 618 Geochimica et Cosmochimica Acta 189, 214-235.

619 Hedges, J. I., Keil, R. G., 1995. Sedimentary organic matter preservation: an assessment 620 and speculative synthesis. Marine Chemistry 49, 81-115.

621 Ingall, E., Jahnke, R., Jun. 1994. Evidence for enhanced phosphorus regeneration from 622 marine sediments overlain by oxygen depleted waters. Geochimica et Cosmochimica 623 Acta 58, 2571-2575. 
624 Janssen, D. J., Conway, T. M., John, S. G., Christian, J. R., Kramer, D. I., Pedersen, 625 T. F., Cullen, J. T., 2014. Undocumented water column sink for cadmium in open ocean 626 oxygen-deficient zones. PNAS 111, 6888-6893.

627 Janssen, D. J., Cullen, J. T., 2015. Decoupling of zinc and silicic acid in the subarctic 628 northeast Pacific interior. Marine Chemistry 177, 124-133.

629 Jickells, T. D., An, Z. S., Andersen, K. K., Baker, A. R., Bergametti, G., Brooks, N., Cao, 630 J. J., Boyd, P. W., Duce, R. A., Hunter, K. A., Kawahata, H., Kubilay, N., laRoche, J., 631 Liss, P. S., Mahowald, N., Prospero, J. M., Ridgwell, A. J., Tegen, I., Torres, R., 2005. 632 Global Iron Connections Between Desert Dust, Ocean Biogeochemistry, and Climate. 633 Science 308, 67-71.

634 Kasting, J., 2005. Methane and climate during the Precambrian era. Precambrian Re635 search 137, 119-129.

636 Konhauser, K. O., Pecoits, E., Lalonde, S. V., Papineau, D., Nisbet, E. G., Barley, 637 M. E., Arndt, N. T., Zahnle, K., Kamber, B. S., 2009. Oceanic nickel depletion and a 638 methanogen famine before the Great Oxidation Event. Nature 458, nature07858.

639 Lai, X., Norisuye, K., Mikata, M., Minami, T., Bowie, A. R., Sohrin, Y., 2008. Spatial 640 and temporal distribution of $\mathrm{Fe}, \mathrm{Ni}, \mathrm{Cu}$ and $\mathrm{Pb}$ along $140^{\circ} \mathrm{E}$ in the Southern Ocean 641 during austral summer 2001/02. Marine Chemistry 111, 171-183.

642 Landing, W. M., Lewis, B. L., 1991. Thermodynamic Modeling of Trace Metal Speciation 643 in the Black Sea. In: Black Sea Oceanography. NATO ASI Series. Springer, Dordrecht, 644 pp. $125-160$.

645 Little, S., Vance, D., Walker-Brown, C., Landing, W., 2014. The oceanic mass balance 646 of copper and zinc isotopes, investigated by analysis of their inputs, and outputs to 647 ferromanganese oxide sediments. Geochimica et Cosmochimica Acta 125, 673-693. 
648 Little, S. H., Vance, D., Lyons, T. W., McManus, J., 2015. Controls on trace metal 649 authigenic enrichment in reducing sediments: Insights from modern oxygen-deficient 650 settings. American Journal of Science 315, 77-119.

651 Mackey, D. J., O’Sullivan, J. E., Watson, R. J., Dal Pont, G., 2002. Trace metals in the 652 Western Pacific: temporal and spatial variability in the concentrations of $\mathrm{Cd}, \mathrm{Cu}, \mathrm{Mn}$ 653 and Ni. Deep Sea Research Part I: Oceanographic Research Papers 49, 2241-2259.

654 Oelkers, E. H., Jones, M. T., Pearce, C. R., Jeandel, C., Eiriksdottir, E. S., Gislason, 655 S. R., 2012. Riverine particulate material dissolution in seawater and its implications 656 for the global cycles of the elements. Comptes Rendus Geoscience 344, 646-651.

657 Ohnemus, D. C., Rauschenberg, S., Cutter, G. A., Fitzsimmons, J. N., Sherrell, R. M., 658 Twining, B. S., 2016. Elevated trace metal content of prokaryotic communities associ659 ated with marine oxygen deficient zones. Limnology and Oceanography 62, 3-25.

660 Paytan, A., McLaughlin, K., Feb. 2007. The Oceanic Phosphorus Cycle. Chem. Rev. 107, $661563-576$.

662 Peacock, C. L., Sherman, D. M., 2007. Sorption of Ni by birnessite: Equilibrium controls 663 on Ni in seawater. Chemical Geology 238, 94-106.

664 Pons, M.-L., Fujii, T., Rosing, M., Quitté, G., Télouk, P., Albaréde, F., 2013. A Zn 665 isotope perspective on the rise of continents. Geobiology 11, 201-214.

666 Ragsdale, S. W., 2009. Nickel-based Enzyme Systems. Journal of Biological Chemistry $667284,18571-18575$.

668 Ragueneau, O., Dittert, N., Pondaven, P., Tréguer, P., Corrin, L., 2002. Si/C decoupling 669 in the world ocean: is the Southern Ocean different? Deep Sea Research Part II: Topical 670 Studies in Oceanography 49, 3127-3154.

671 Revels, B., Rickli, J., Moura, C., Vance, D., 2017. Phase Partitioning of Transition Metals 672 and their Isotopes in the Particulate Load of the Amazon River. Goldschmidt Abstracts, 
673

674 675 676 677 678 679 680 681 682 683 684 685 686 687 688 689 690 691 1-11.

692 Tréguer, P., Nelson, D. M., Van Bennekom, A. J., Demaster, D. J., Leynaert, A., 693 Quéguiner, B., 1995. The silica balance in the world ocean: a reestimate. Science 268, $694 \quad 375-379$.

695 Twining, B. S., Baines, S. B., Bozard, J. B., Vogt, S., Walker, E. A., Nelson, D. M., 2011. 696 Metal quotas of plankton in the equatorial Pacific Ocean. Deep Sea Research Part II: 697 Topical Studies in Oceanography 58, 325-341. 
698 Twining, B. S., Baines, S. B., Vogt, S., Nelson, D. M., Dec. 2012. Role of diatoms in 699 nickel biogeochemistry in the ocean. Global Biogeochemical Cycles 26, GB4001.

700 Vance, D., Little, S. H., Archer, C., Cameron, V., Andersen, M. B., Rijkenberg, M. J. A., 701 Lyons, T. W., 2016. The oceanic budgets of nickel and zinc isotopes: the importance 702 of sulfidic environments as illustrated by the Black Sea. Philosophical Transactions of 703 the Royal Society A: Mathematical, Physical and Engineering Sciences 374, 20150294.

704 Wheat, C. G., Mottl, M. J., Rudnicki, M., 2002. Trace element and REE composition of 705 a low-temperature ridge-flank hydrothermal spring. Geochimica et Cosmochimica Acta $706 \quad 66,3693-3705$.

\section{Figure captions}

708 Fig.1: Published Ni isotope data for seawater compared to that of the discharge 709 weighted average for the dissolved phase of rivers (turquoise line) and to that of the up710 per continental crust (UCC, brown line). Data from Cameron and Vance (2014) and 711 Takano et al. (2017).

712

713 Fig.2: Map of sample provenance (a). Details of the Peru margin setting (b) where 714 core-top samples (black diamonds) and three down-core profiles (colorful symbols) were 715 taken. Grey shading indicates bathymetry whereas colors indicate bottom water oxygen. 716 Oxygen data from CTD casts was gridded in ODV with DIVA scaling. Details of the 717 Lagoa Salgada setting(c) modified from Birgel et al. (2015).

718

719 Fig.3: TOC data for the bulk samples, measured before any HF-HCl treatment, plotted 720 versus the TOC content of the OPF, obtained after the $\mathrm{HF}-\mathrm{HCl}$ digestion. Plotted error 721 bars reflect the repeatability of standards and samples and are $\pm 15 \%$ (relative). Most 722 data fall on an array (solid line, slope $=0.9$ ) that implies $90 \%$ retention of the organic 723 carbon in the OPF after the HF digestion. The dashed lines bracket nearly all the data 
and have slopes of 0.6 and 1.2 .

725

726 Fig.4: Peru margin Ni abundances and isotope composition calculated for bulk sam-

727 ples (a) and as measured for the respective OPF and HFD fractions of the same samples 728 (b). The blue line and associated band indicate the average and $2 \sigma$ of the Ni isotopic 729 composition of the modern deep ocean (defined by depths greater than $1000 \mathrm{~m}$, references 730 in text).

731

732 Fig.5: Ni abundances plotted versus TOC for the sediments studied here. (a) Data 733 for Peru Margin bulk sediments, compared to data reported in Böning et al. (2015) for 734 sediments in upwelling regions globally. The strong correlation between Ni abundance 735 and TOC in the OMZ sediments suggests delivery of $\mathrm{Ni}$ to the sediments via organic 736 matter (data in gray from Böning et al., 2015). (b) Ni/Al vs. TOC for the Peru Margin 737 sediments studied here. The $\mathrm{Ni}$ organic matter association for Peru margin samples is 738 further supported by (c) the correlation between $\mathrm{Ni}$ abundance in the OPF fraction versus 739 \%orgC in the $\mathrm{OPF}$ and $(\mathrm{d})$ the strong correlation between $\mathrm{Ni}$ and $\mathrm{P}$ abundances in the 740 OPF fraction in all but two of the Peru Margin samples.

742 Fig.6: $\delta^{60} \mathrm{Ni}$ vs. $\ln [\mathrm{Ni}]$ in the organic-pyrite fractions (OPF) of Peru Margin and Lagoa 743 Salgada sediments. Most Peru Margin samples for cores within the OMZ, as well as all 744 core-top samples, lie on an array that is consistent with removal of Ni from a water col745 umn with a Ni isotopic composition close to the deep ocean value. The arrow labeled $746 \alpha=0.9997$ shows the expected array if the $\mathrm{Ni}$ in the OPF is derived from the photic zone 747 with preferential removal of the light isotope as observed in the water column (Archer 748 et al., 2017; Takano et al., 2017). Most of the data for the Peru Margin samples are 749 consistent with this process. Data for both the Peru Margin core from beneath the OMZ 750 and the Lagoa Salgada may define a fractionation trend representing an alpha that is 751 closer to 1. 
753 Fig.7: $\delta^{60} \mathrm{Ni}$ vs. $\delta^{13} \mathrm{C}$. Peru margin down-core sediments from the upper edge of and 754 below the OMZ show inverse correlations between $\delta^{60} \mathrm{Ni}$ and $\delta^{13} \mathrm{C}$ of the OPF fraction 755 that appear to be specific to each location. (b) Lagoa Salgada OPF fractions exhibit an 756 opposite (positive) correlation between $\delta^{60} \mathrm{Ni}$ and $\delta^{13} \mathrm{C}$.

757

758 Fig.8: Peru Margin authigenic $\delta^{60} \mathrm{Ni}$ obtained after a correction for detrital Ni, using $759 \mathrm{Ni} / \mathrm{Al}$ detrital of 0 (i.e., no correction, filled symbols) and of $3.3^{*} 10^{-4} \mathrm{~g} / \mathrm{g}$ (empty sym760 bols). The bars between the empty and filled symbol of each sample indicate the range

761 along which the $\delta^{60} \mathrm{Ni}_{\text {authigenic }}$ could lie. The blue line and associated band indicate the 762 average and $2 \sigma$ of the $\mathrm{Ni}$ isotopic composition of the modern deep ocean (defined by 763 depths greater than $1000 \mathrm{~m}$, references in text).

764

765 Fig.9: Requirements of two alternative ways to balance the oceanic budget of $\mathrm{Ni}$ and 766 its isotopes. The black curve shows the required isotope composition of a projected 767 missing input versus its size, given a range in size of the Fe-Mn oxide output from that 768 required to balance the currently known inputs (missing input $=$ zero) up to $1.5^{*} 10^{9}$ $769 \mathrm{~mol} / \mathrm{yr}$ (Cameron and Vance, 2014). The $\delta^{60} \mathrm{Ni}$ of the Fe-Mn oxide output is taken to be 770 the average of data in Gall et al. (2013). The red curve assumes that the required missing 771 input has an isotope composition the same as the upper continental crust, and explores 772 the $\delta^{60} \mathrm{Ni}$ of the effective - e.g. final buried - Fe-Mn oxide output following potential 773 diagenetic modification. Other parameters, for the size and isotopic composition of the 774 better known inputs and outputs, as summarized in Table 3. 
Table 1: Elemental and isotope data for Peru Margin and Lagoa Salgada sediments.

\begin{tabular}{|c|c|c|c|c|c|c|c|c|c|c|c|c|c|c|c|c|c|c|c|c|c|c|c|}
\hline sample & $\begin{array}{l}\text { water depth or } \\
\text { depth in core } \\
(\mathrm{m}) \text { or }(\mathrm{cm})\end{array}$ & $\begin{array}{c}\mathrm{BWO}^{1} \\
(\mu \mathrm{M})\end{array}$ & $\mathrm{wt} \%^{2}$ & $\underset{(w t \%)}{\mathrm{C}}$ & $\begin{array}{l}\delta^{13} \mathrm{C} \\
(\%)\end{array}$ & $\begin{array}{c}\mathrm{Ni} \\
(\mathrm{ppm})^{3}\end{array}$ & $\begin{array}{c}\mathrm{OPF} \\
\mathrm{Ni} \\
\text { (\% of tot) }\end{array}$ & $\begin{array}{c}\mathrm{Al} \\
\text { (wt \%) }\end{array}$ & $\begin{array}{c}\mathrm{P} \\
(\mathrm{ppm})\end{array}$ & $\begin{array}{l}\delta^{60} \mathrm{Ni} \\
(\%))\end{array}$ & $2 \sigma^{4}$ & $\begin{array}{c}\mathrm{Ni} \\
(\mathrm{ppm})\end{array}$ & $\begin{array}{c}\mathrm{Ni} \\
\text { (\% of tot) }\end{array}$ & $\begin{array}{c}\text { HFD } \\
\text { Al } \\
\text { (wt\%) }\end{array}$ & $\begin{array}{c}\delta^{60} \mathrm{Ni} \\
(\%)\end{array}$ & $2 \sigma$ & $\begin{array}{l}\mathrm{TOC} \\
(\mathrm{wt} \%)\end{array}$ & $\begin{array}{l}\delta^{13} \mathrm{C} \\
(\%)\end{array}$ & $\begin{array}{c}\mathrm{Ni} \\
(\mathrm{ppm})\end{array}$ & $\begin{array}{c}\text { Bulk }^{6} \\
\text { Al } \\
\text { (wt\%) }\end{array}$ & $\mathrm{Ni} / \mathrm{Al}^{5}$ & $\begin{array}{l}\delta^{60} \mathrm{Ni} \\
(\%)\end{array}$ & $2 \sigma$ \\
\hline \multicolumn{24}{|c|}{ 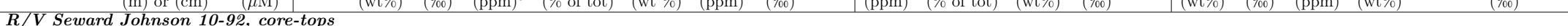 } \\
\hline BC39 & 550 & 10 & 20 & 3.4 & -20.9 & 9.8 & 14 & 10 & 325 & 1.24 & 0.10 & 61 & 86 & 23 & 106 & 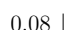 & 3.4 & -211 & 70 & 33 & 21 & 109 & 0.08 \\
\hline BC57 & 172 & $<10$ & 34 & $\begin{array}{l}0.4 \\
12\end{array}$ & -20.8 & 13 & 15 & 0.7 & 99 & 1.02 & 0.08 & 76 & 85 & 4.1 & 1.07 & 0.08 & $\begin{array}{l}9.6 \\
9.6\end{array}$ & -20.5 & 89 & 1.8 & 21 & 1.06 & 0.08 \\
\hline BC62 & 643 & 10 & $\begin{array}{l}34 \\
21\end{array}$ & 4.4 & $\begin{array}{l}-21.0 \\
-21.3\end{array}$ & 7.5 & 17 & $\begin{array}{l}0.1 \\
0.9\end{array}$ & 34 & $\begin{array}{l}1.02 \\
1.08\end{array}$ & 0.05 & 38 & 83 & $\begin{array}{l}4.1 \\
5.2\end{array}$ & $\begin{array}{l}1.01 \\
1.26\end{array}$ & 0.05 & $\begin{array}{l}5.0 \\
5.0\end{array}$ & $\begin{array}{l}-20.0 \\
-20.9\end{array}$ & 45 & $\begin{array}{l}6.0 \\
6.1\end{array}$ & 7.4 & 1.23 & 0.05 \\
\hline BC76 & 725 & 15 & 30 & 4.9 & -21.2 & 8.5 & 17 & 1.5 & 48 & 1.15 & 0.10 & 42 & 83 & 4.8 & 1.37 & 0.07 & 6.6 & -21.1 & 50 & 6.2 & 8 & 1.33 & 0.08 \\
\hline BC81 & 130 & 10 & 36 & 11 & -20.7 & 17 & 21 & 1.1 & 71 & 1.15 & 0.06 & 62 & 79 & 4.5 & 1.08 & 0.08 & 10.6 & $\mathrm{n} / \mathrm{a}$ & 79 & 5.6 & 14 & 1.09 & 0.07 \\
\hline KC 83 & 106 & 10 & 44 & 7.9 & -20.4 & 12 & 24 & 1.3 & 71 & 1.14 & 0.07 & 37 & 76 & 3.0 & 1.04 & 0.05 & 7.8 & -20.2 & 49 & 4.4 & 11 & 1.07 & 0.06 \\
\hline BC93 & 100 & 5 & 25 & 3.4 & -20.8 & 5.6 & 16 & 0.3 & 20 & 1.30 & 0.08 & 29 & 84 & 5.1 & 1.05 & 0.06 & 3.7 & -20.5 & 35 & 5.4 & 6.5 & 1.09 & 0.06 \\
\hline BC125 & 340 & 5 & 36 & $\begin{array}{l}5.4 \\
7.6\end{array}$ & -21.3 & 10 & 13 & 0.7 & 94 & 0.91 & 0.10 & 65 & 87 & 4.7 & $\begin{array}{l}1.00 \\
1.20\end{array}$ & 0.07 & 8.1 & -20 & 75 & $\begin{array}{l}5.4 \\
5.4\end{array}$ & 14 & 1.16 & 0.08 \\
\hline KC127 & $\begin{array}{l}540 \\
309\end{array}$ & 5 & 45 & $\begin{array}{l}4.0 \\
4.1\end{array}$ & $\begin{array}{l}-20.0 \\
-20.9\end{array}$ & 16 & 18 & 0.4 & $\begin{array}{l}54 \\
57\end{array}$ & 1.04 & 0.07 & 70 & $\begin{array}{l}81 \\
82\end{array}$ & $\begin{array}{l}\text { l.1 } \\
2.6\end{array}$ & $\begin{array}{l}1.20 \\
1.17\end{array}$ & 0.07 & $\begin{array}{l}0.1 \\
9.9\end{array}$ & $\begin{array}{l}-20.1 \\
-20.6\end{array}$ & 85 & $\begin{array}{l}5.4 \\
3.0\end{array}$ & $\begin{array}{l}14 \\
29\end{array}$ & 1.15 & $\begin{array}{l}0.00 \\
0.07\end{array}$ \\
\hline $\mathrm{BC} 153$ & 250 & & 51 & 8.7 & -20.9 & 9.4 & 11 & 0.1 & 29 & 0.98 & 0.09 & 75 & 89 & 2.5 & 1.14 & 0.06 & 9.7 & -20.8 & 84 & 2.6 & 32 & 1.12 & 0.08 \\
\hline \multicolumn{24}{|c|}{ R/V Knorr 182-9, core MC6A, $100 m$ water depth, upper $O M Z$} \\
\hline MC6A1 & 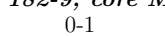 & 2.2 & 34 & 2.9 & -21.2 & 7.8 & 20 & 0.7 & 21 & 1.28 & 0.07 & 30 & 80 & 2.6 & 1.04 & 0.08 & 5.4 & $\mathrm{n} / \mathrm{a}$ & 38 & 3.3 & 13 & 1.09 & 0.07 \\
\hline MC6A6 & $5-6$ & 2.2 & 36 & 4.0 & -20.4 & 9.6 & 21 & 0.8 & 29 & 1.28 & 0.07 & 36 & 79 & 2.3 & 0.92 & 0.07 & 5.9 & -20.7 & 46 & 3.2 & 16 & 0.99 & 0.07 \\
\hline MC6A14 & $13-14$ & 2.2 & 32 & $\begin{array}{l}3.0 \\
3.7\end{array}$ & $\begin{array}{l}-20.4 \\
-2.3\end{array}$ & $\begin{array}{l}9.0 \\
9.6\end{array}$ & 21 & 0.9 & 39 & 1.28 & 0.07 & 37 & 79 & $\begin{array}{l}2.0 \\
2.6\end{array}$ & 0.86 & 0.07 & 6.0 & $\begin{array}{l}-20 \\
-10\end{array}$ & 47 & $\begin{array}{l}3.2 \\
3.4\end{array}$ & 5 & 0.94 & 0.07 \\
\hline MC6A16 & $15-16$ & 2.2 & $\begin{array}{l}32 \\
30\end{array}$ & $\begin{array}{l}.1 .1 \\
3.4\end{array}$ & $\begin{array}{l}-21.0 \\
-21.2\end{array}$ & 11 & 24 & 1.1 & 23 & $\begin{array}{l}1.20 \\
\mathrm{n} / \mathrm{a}\end{array}$ & n/a & 36 & 76 & $\begin{array}{l}2.0 \\
3.3\end{array}$ & $\begin{array}{l}0.00 \\
\mathrm{n} / \mathrm{a}\end{array}$ & $\mathrm{n} / \mathrm{a}$ & $\begin{array}{l}5.0 \\
5.1\end{array}$ & $\begin{array}{l}-21.1 \\
-21.2\end{array}$ & 47 & $\begin{array}{l}5.4 \\
4.4\end{array}$ & 11 & $\begin{array}{l}\mathrm{n} / \mathrm{a} \\
\mathrm{n}\end{array}$ & $\mathrm{n} / \mathrm{a}$ \\
\hline MC6A22 & $21-22$ & 2.2 & 22 & 2.2 & -22.2 & 6.0 & 20 & 0.9 & 18 & 1.71 & 0.08 & 25 & 80 & 3.2 & 0.97 & 0.08 & 3.3 & -22.2 & 31 & 4.1 & 8.4 & 1.11 & 0.08 \\
\hline MC6A26 & $25-26$ & 2.2 & 24 & 2.9 & -21.8 & 9.1 & 24 & 1.2 & 28 & 1.83 & 0.07 & 29 & 76 & 3.1 & 0.90 & 0.09 & 4.0 & -21.8 & 38 & 4.2 & 10 & 1.12 & 0.09 \\
\hline MC6A 37 & $36-37$ & 2.2 & 19 & 3.2 & -20.8 & 15 & 30 & 0.5 & 31 & $\mathrm{n} / \mathrm{a}$ & $\mathrm{n} / \mathrm{a}$ & 35 & 70 & $\begin{array}{l}3.1 \\
3.2\end{array}$ & $\mathrm{n} / \mathrm{a}$ & $\mathrm{n} / \mathrm{a}$ & 5.1 & -20.9 & 50 & $\begin{array}{l}3.7 \\
3.7\end{array}$ & 13 & $\mathrm{n} / \mathrm{a}$ & $\mathrm{n} / \mathrm{a}$ \\
\hline \multirow{2}{*}{\multicolumn{24}{|c|}{ C $9 G, 1500 m$ water depth, below $O M Z$}} \\
\hline & & & & & & & & & & & & & & & & & & & & & & & \\
\hline MC9G1 & $0-1$ & 80 & 19 & 1.0 & -21.5 & 2.1 & 11 & 0.4 & 18 & 1.21 & 0.08 & 17 & 89 & 3.4 & 1.15 & 0.08 & 1.6 & $\mathrm{n} / \mathrm{a}$ & 19 & 3.8 & 5.9 & 1.16 & 0.08 \\
\hline MC9G3 & $2-3$ & 80 & 19 & 1.1 & -21.4 & 2.7 & 13 & 0.4 & 31 & $\mathrm{n} / \mathrm{a}$ & $\mathrm{n} / \mathrm{a}$ & 18 & 87 & 3.5 & $\mathrm{n} / \mathrm{a}$ & $\mathrm{n} / \mathrm{a}$ & 2.2 & -21.6 & 21 & 3.9 & 5.3 & $\mathrm{n} / \mathrm{a}$ & $\mathrm{n} / \mathrm{a}$ \\
\hline MC9G5 & $4-5$ & 80 & 16 & 1.0 & -21.1 & 2.2 & 12 & 0.4 & 17 & $\mathrm{n} / \mathrm{a}$ & $\mathrm{n} / \mathrm{a}$ & 17 & 88 & 3.7 & $\mathrm{n} / \mathrm{a}$ & $\mathrm{n} / \mathrm{a}$ & 2.0 & -21.6 & 19 & 4.1 & 4.6 & $\mathrm{n} / \mathrm{a}$ & $\mathrm{n} / \mathrm{a}$ \\
\hline MC9G7 & $6-7$ & 80 & 14 & 1.0 & -20.9 & 0.8 & 4.2 & 0.2 & 6.6 & 1.13 & 0.09 & 18 & 96 & 4.0 & 1.12 & 0.05 & 1.8 & -21.7 & 18 & $\begin{array}{l}4.2 \\
\text { S }\end{array}$ & 4.9 & 1.12 & 0.06 \\
\hline MC9G9 & 8-9 & 80 & 15 & 1.0 & -21.2 & 1.4 & 7.3 & 0.4 & 8.5 & $\mathrm{n} / \mathrm{a}$ & $\mathrm{n} / \mathrm{a}$ & 18 & 93 & 3.8 & $\mathrm{n} / \mathrm{a}$ & $\mathrm{n} / \mathrm{a}$ & 2.3 & -21.6 & 19 & 4.2 & 6 & $\mathrm{n} / \mathrm{a}$ & $\mathrm{n} / \mathrm{a}$ \\
\hline MC9G11 & $10-11$ & 80 & 17 & 1.2 & -20.5 & $\begin{array}{l}2.7 \\
2.7\end{array}$ & 12 & 0.3 & 8.4 & 0.96 & $\begin{array}{l}117 \mathrm{a} \\
0.09\end{array}$ & 19 & 88 & $\begin{array}{l}3.0 \\
3.7\end{array}$ & 1.15 & 0.06 & 1.6 & $\mathrm{n} / \mathrm{a}$ & 22 & 4.0 & 6.0 & 1.12 & 0.06 \\
\hline MC9G13 & $12-13$ & 80 & 14 & 1.2 & -20.6 & 2.1 & 11 & 0.4 & 8.1 & 1.02 & 0.08 & 17 & 89 & 3.5 & 1.18 & 0.07 & 1.7 & -21.8 & 2. & 3.9 & 0 & 1.16 & 0.07 \\
\hline \multicolumn{24}{|c|}{$R / V$ Knorr $182-9$, core $M C 11 C, 325 m$ water depth, within $O M Z$} \\
\hline $\mathrm{MC} 11 \mathrm{C} 4$ & $3-4$ & 2.1 & 43 & 16 & -21.2 & 25 & 18 & 0.7 & 139 & 0.96 & 0.08 & 112 & 82 & 1.7 & 1.20 & 0.09 & 14.2 & -21.3 & 138 & 2.4 & 66 & 1.16 & 0.09 \\
\hline MC11C8 & $7-8$ & 2.1 & 35 & 10 & -21.8 & 22 & 17 & 0.7 & 123 & 0.94 & 0.05 & 104 & 83 & 1.8 & 1.20 & 0.09 & 12.9 & -21.7 & & 2.6 & 55 & 1.15 & 0.08 \\
\hline MC11C17 & $16-17$ & 2.1 & 31 & 7.1 & -22.0 & 22 & 19 & 0.9 & 128 & 0.98 & 0.06 & 95 & 81 & $\begin{array}{l}1.0 \\
2.2\end{array}$ & 1.27 & 0.12 & 11.8 & -21.7 & 11 & $\begin{array}{l}3.0 \\
3.1\end{array}$ & 41 & 1.21 & 0.11 \\
\hline $\mathrm{MC} 11 \mathrm{C} 23$ & $22-23$ & 2.1 & 30 & 8.0 & -21.9 & 23 & 20 & 0.8 r & 133 & $\mathrm{n} / \mathrm{a}$ & $\mathrm{n} / \mathrm{a}$ & 9 & 8 & 2.1 & $\mathrm{n} / \mathrm{a}$ & $\mathrm{n} / \mathrm{a}$ & 11 & -21.7 & 1 & 2.9 & 41 & $\mathrm{n} / \mathrm{a}$ & $\mathrm{n} / \mathrm{a}$ \\
\hline MC & $27-28$ & 2.1 & 30 & $\begin{array}{l}0.0 \\
7.1\end{array}$ & $\begin{array}{l}-21 \\
-21\end{array}$ & 22 & 17 & 0.7 & 98 & 0.86 & 0.0 & 10 & 83 & 2. & 1.17 & 0.07 & 12 & -21.8 & 127 & 3.3 & 42 & 1.11 & 0.07 \\
\hline MC11 & $34-35$ & 2.1 & 15 & 5.1 & $\begin{array}{l}-22.0 \\
-2.0\end{array}$ & 16 & 20 & 3 & 86 & 0.93 & 0.06 & 66 & 80 & 2.2 & 1.22 & 0.06 & 10.3 & $\mathrm{n}$ & 82 & 2.5 & 36 & 1.16 & 0.06 \\
\hline MC11C37 & $36-37$ & 2.1 & 29 & 6.6 & -21.7 & 26 & 19 & 0.9 & 176 & $\mathrm{n} / \mathrm{a}$ & $\mathrm{n} / \mathrm{a}$ & 113 & 81 & 2.3 & $\mathrm{n} / \mathrm{a}$ & $\mathrm{n} / \mathrm{a}$ & 12.6 & -21.4 & 139 & 3.2 & 44 & $\mathrm{n} / \mathrm{a}$ & $\mathrm{n} / \mathrm{a}$ \\
\hline & 46-48 & 2.1 & 31 & 9.4 & -21.6 & 26 & 20 & 1.0 & 334 & $\mathrm{n} / \mathrm{a}$ & $\mathrm{n} / \mathrm{a}$ & 102 & 80 & 1.7 & n/a & $\mathrm{n} / \mathrm{a}$ & 10.8 & -21.4 & 127 & 2.8 & 46 & $\mathrm{n} / \mathrm{a}$ & $\mathrm{n} / \mathrm{a}$ \\
\hline \multicolumn{24}{|c|}{ Lagoa Salgada } \\
\hline LS14 & $14.8-15.8$ & $\mathrm{n} / \mathrm{a}$ & 12 & 5.2 & -11.3 & 0.31 & 13 & 0.04 & 8.5 & 1.58 & 0.05 & 2.0 & 87 & 0.80 & 0.41 & 0.15 & 7.4 & $\mathrm{n} / \mathrm{a}$ & 2.3 & 0.84 & 2.7 & 0.46 & 0.14 \\
\hline LS2 & 20 & $\mathrm{n}$ & 10 & 1. & -15.8 & 0.17 & 6 & 0 & 3 & 1.21 & 0.06 & 2. & 93 & 0.8 & 0 & 0.11 & . & $\mathrm{n} / \mathrm{a}$ & 2. & 0. & 7 & 0.34 & 0.11 \\
\hline LS & $24.8-25.8$ & $\mathrm{n} / \mathrm{a}$ & 13 & 2.4 & -10.8 & 0.19 & 10 & & 5.1 & 1. & 0.06 & 1.8 & 90 & 0.77 & 0.13 & 0.05 & 3.2 & $\mathrm{n} / \mathrm{a}$ & 2.0 & 0.93 & 2.1 & 0.21 & 0.05 \\
\hline LS30 & $29.8-30.8$ & $\mathrm{n} / \mathrm{a}$ & 9.1 & 0.9 & -7.0 & 0.07 & 3.4 & 0.2 & 2.9 & 1.58 & 0.08 & 2.1 & 97 & 0.72 & 0.10 & 0.07 & 2.4 & $\mathrm{n} / \mathrm{a}$ & 2.1 & 0.94 & 2.3 & 0.12 & 0.07 \\
\hline LS35 & $34.8-35.8$ & n/a & 10 & 1.5 & -7.6 & 0.24 & 6.7 & 0.4 & 4.8 & 1.31 & 0.08 & 3.3 & 93 & 0.91 & -0.03 & 0.06 & 2.4 & $\mathrm{n} / \mathrm{a}$ & 3.5 & 1.3 & 2.7 & 0.04 & 0.06 \\
\hline LS40 & $39.8-40.8$ & n/a & 11 & 1.6 & -9.0 & 0.21 & 6.3 & 0.4 & 5.6 & 1.34 & 0.05 & 3.0 & 94 & 0.80 & 0.04 & 0.07 & 2.1 & $\mathrm{n} / \mathrm{a}$ & 3.3 & 1.2 & 2.7 & 0.10 & 0.07 \\
\hline LS4 & $44.8-4$ & $\mathrm{n} / \mathrm{a}$ & 6.0 & 1.3 & -10.2 & 0.20 & 5. & 0.1 & 3. & 1.3 & 0.0 & 3.6 & 95 & 1. & 0.11 & 0.0 & 3. & $\mathrm{n}$ & 3. & 1.4 & 2. & 0.15 & 0.08 \\
\hline LS65 & $\begin{array}{l}4.0-4.0 \\
65.8-66.6\end{array}$ & $\begin{array}{l}\text { n } \\
\mathrm{n} / \mathrm{a}\end{array}$ & $\begin{array}{l}2.0 \\
27\end{array}$ & $\begin{array}{l}1.0 \\
2.3\end{array}$ & -23.5 & 0.71 & 4.8 & 1.1 & $\begin{array}{l}.0 \\
1.2\end{array}$ & 1.10 & $\begin{array}{l}.00 \\
0.04\end{array}$ & $\begin{array}{l}.0 \\
14\end{array}$ & 95 & 1.3 & $\mathrm{n} / \mathrm{a}$ & $\begin{array}{l}.00 \\
\mathrm{n} / \mathrm{a}\end{array}$ & $\begin{array}{l}3.2 \\
3.4\end{array}$ & n/a & 15 & 2.4 & 6.1 & $\mathrm{n} / \mathrm{a}$ & $\mathrm{n} / \mathrm{a}$ \\
\hline
\end{tabular}

${ }^{1}$ Water depth for R/V Seward Johnson samples and depth in core for all other samples; BWO is bottom water oxygen: TOC measured in bulk sample. ${ }^{2}$ wt\% of total sample found to be in the OPF. ${ }^{3}$ Nickel concentrations obtained from the Element analysis. Nickel concentrations obtained by Element analysis and isotope dilution agree to within 10-20\%, but Element concentrations are used in all diagrams because of the importance of Ni/Al ratios to the interpretation. ${ }^{4}$ The $2 \sigma$ uncertainties reported here are internal errors propagated through the double spike reduction procedure. ${ }^{5} \mathrm{All} \mathrm{Ni} / \mathrm{Al}$ ratios are to be ${ }^{*} 10^{-4}$. ${ }^{6} \mathrm{Data}$ for the 'Bulk' are calculated as the sum of the OPF and HFD fractions. 
Table 2: Ni amounts, fluxes, and isotope compositions relevant to the modern oceanic mass balance.

\begin{tabular}{|c|c|c|c|c|c|c|c|c|c|c|c|}
\hline \multirow[t]{2}{*}{ Reservoir } & \multirow[t]{2}{*}{ Mass flux } & \multirow[t]{2}{*}{$\operatorname{Ref}^{*}$} & \multicolumn{2}{|l|}{$\mathrm{Ni}$ concentration } & \multirow[t]{2}{*}{$\operatorname{Ref}^{*}$} & \multicolumn{2}{|c|}{$\mathrm{Ni}$ flux (mol/yr) } & \multirow[t]{2}{*}{$\operatorname{Ref}^{*}$} & \multicolumn{2}{|l|}{$\delta^{60} \mathrm{Ni}(\%)$} & \multirow[t]{2}{*}{$\operatorname{Ref}^{*}$} \\
\hline & & & range & best estimate & & range & best estimate & & range & best estimate & \\
\hline Global oceans & & & $2.0-12 \mathrm{nM}$ & $8.0 \mathrm{nM}$ & 1 & & & & $1.20-1.74$ & 1.39 & $2-3$ \\
\hline \multicolumn{12}{|l|}{ Input fluxes } \\
\hline Rivers & & & $2.5-35 \mathrm{nM}$ & $9.6 \mathrm{nM}$ & 2 & & $3.6^{*} 10^{8}$ & 2 & & 0.80 & 2 \\
\hline \multirow[t]{3}{*}{ Dust } & $4.50^{*} 10^{11} \mathrm{~kg} / \mathrm{yr}$ & 4 & $36-58 \mathrm{ppm}$ & $47 \mathrm{ppm}$ & 5 & $2.7-4.5 * 10^{8}$ & $3.6^{*} 10^{8}$ & & $-0.09-0.37$ & 0.14 & 7 \\
\hline & & & & & & & $2.1 \%$ solubility & 6 & & & \\
\hline & & & & & & $5.8-9.4 * 10^{6}$ & $7.6^{*} 10^{6}$ & & & & \\
\hline Total & & & & & & & $3.7 * 10^{8}$ & & & 0.79 & \\
\hline \multicolumn{12}{|l|}{ Output fluxes } \\
\hline \multirow[t]{2}{*}{ Fe-Mn crusts } & & & & & & & $1.5^{*} 10^{9}$ & 2 & & & \\
\hline & & & & & & & $5.1^{*} 10^{8}$ & 8 & $0.9-2.5$ & 1.6 & 8 \\
\hline \multirow[t]{2}{*}{ Euxinic seds } & $1.0^{*} 10^{12} \mathrm{gC}_{\mathrm{org}} / \mathrm{yr}$ & 9 & $21-70 \mathrm{ppm}$ & $46 \mathrm{ppm}$ & 10 & & & & & & \\
\hline & & & $0.54-1.49 * 10^{-3} \mathrm{Ni} / \mathrm{TOC}$ & $9.0^{*} 10-4 \mathrm{Ni} / \mathrm{TOC}$ & 10,11 & $9.3-25^{*} 10^{7}$ & $1.5^{*} 10^{7}$ & this study & $0.3-0.6$ & 0.45 & 10 \\
\hline \multirow[t]{2}{*}{ OMZ seds } & $1.0^{*} 10^{13} \mathrm{gC}_{\text {org }} / \mathrm{yr}$ & 9 & $21-158 \mathrm{ppm}$ & $69 \mathrm{ppm}$ & this study & & & & & & \\
\hline & & & $0.63-1.56 * 10^{-3} \mathrm{Ni} / \mathrm{TOC}$ & $9.5^{*} 10^{-4} \mathrm{Ni} / \mathrm{TOC}$ & this study & $1.1-2.7^{*} 10^{8}$ & $1.6^{*} 10^{8}$ & this study & $1.19-1.20$ & 1.22 & this study ${ }^{1}$ \\
\hline \multirow[t]{2}{*}{ Carbonates } & $6.0^{*} 10^{12} \mathrm{gC}_{\text {org }} / \mathrm{yr}$ & 9 & $2.2-3.9 \mathrm{ppm}$ & $3.1 \mathrm{ppm}$ & this study & & & & & & \\
\hline & & & $0.30-4.30^{*} 10^{-4} \mathrm{Ni} / \mathrm{TOC}$ & $1.4^{*} 10^{-4} \mathrm{Ni} / \mathrm{TOC}$ & this study & $0.31-4.4 * 10^{7}$ & $1.4^{*} 10^{7}$ & this study & $1.10-1.64$ & 1.29 & this study ${ }^{2}$ \\
\hline \multirow[t]{2}{*}{ Total } & & & & & & $1.6-1.8^{*} 10^{9}$ & $1.7^{*} 10^{9}$ & taking Fe-mn flux as calculated by [3] & $0.92-2.46$ & 1.54 & \\
\hline & & & & & & $6.3-8.5^{*} 10^{8}$ & $7.2^{*} 10^{8}$ & taking Fe-mn flux as calculated by [10] & $0.94-1.99$ & 1.47 & \\
\hline
\end{tabular}

${ }^{*} 1$, Bruland and Lohan (2003); 2, Cameron and Vance (2014); 3, Takano et al. (2017); 4, Jickells et al. (2005); 5, Rudnick and Gao (2014); 6, Desboeufs et al. (2005); 7, Cameron et al. (2009); 8, Gall et al. (2013); 9, Hedges and Keil (1995); 10, Vance et al. (2016); 11, Little et al. (2015). ${ }^{1}$ Obtained using the average authigenic $\delta^{60} \mathrm{Ni}$ for Peru Margin sediments.

${ }^{2}$ Using the Lagoa Salgada OPF samples. 


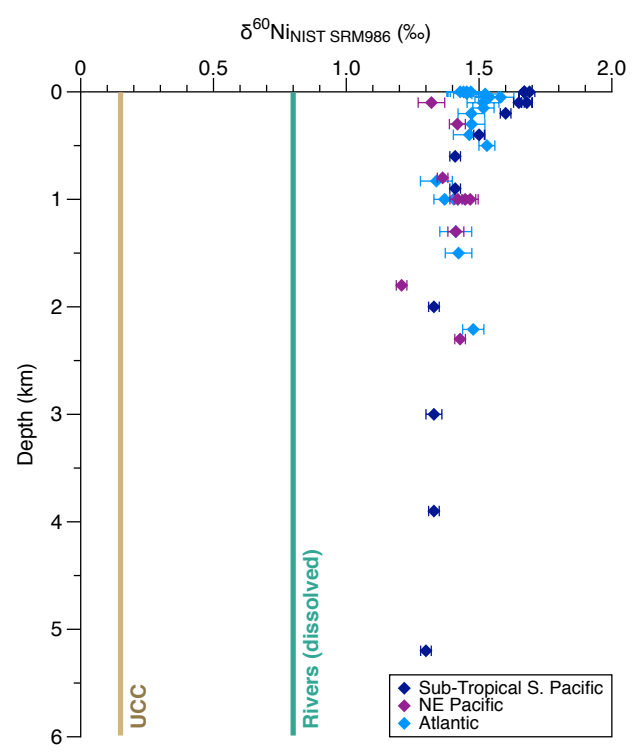

Figure 1: Published Ni isotope data for seawater compared to that of the discharge weighted average for the dissolved phase of rivers (turquoise line) and to that of the upper continental crust (UCC, brown line). Data from Cameron and Vance (2014) and Takano et al. (2017). 
a.

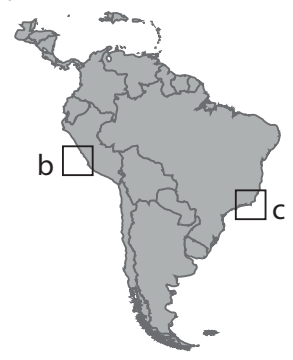

b.

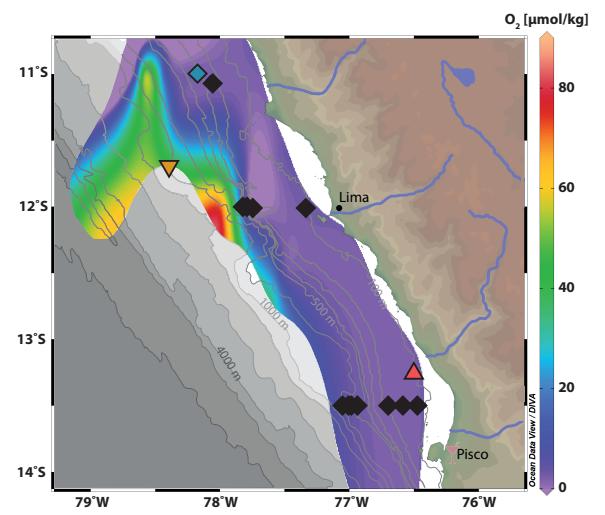

c.

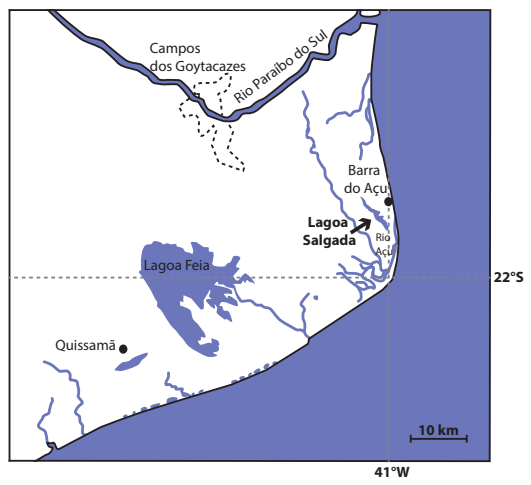

Figure 2: Map of sample provenance (a). Details of the Peru margin setting (b) where core-top samples (black diamonds) and three down-core profiles (colorful symbols) were taken. Grey shading indicates bathymetry whereas colors indicate bottom water oxygen. Oxygen data from CTD casts was gridded in ODV with DIVA scaling. Details of the Lagoa Salgada setting (c) modified from Birgel et al. (2015). 


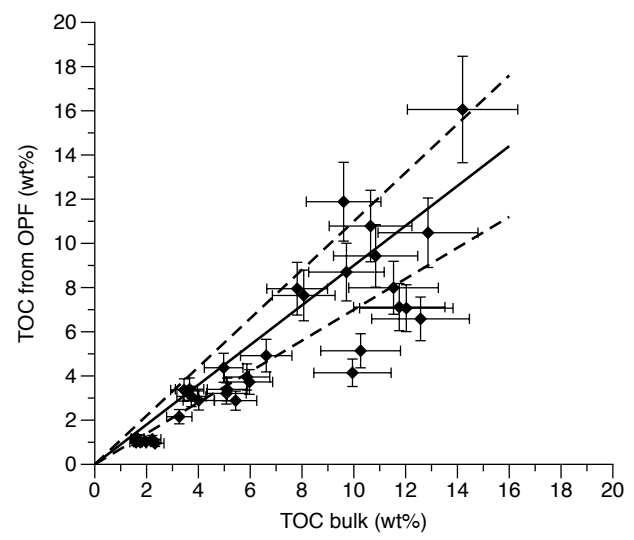

Figure 3: TOC data for the bulk samples, measured before any $\mathrm{HF}-\mathrm{HCl}$ treatment, plotted versus the TOC content of the OPF, obtained after the $\mathrm{HF}-\mathrm{HCl}$ digestion. Plotted error bars reflect the repeatability of standards and samples and are $\pm 15 \%$ (relative). Most data fall on an array (solid line, slope $=0.9$ ) that implies $90 \%$ retention of the organic carbon in the OPF after the HF digestion. The dashed lines bracket nearly all the data and have slopes of 0.6 and 1.2 . 
a.

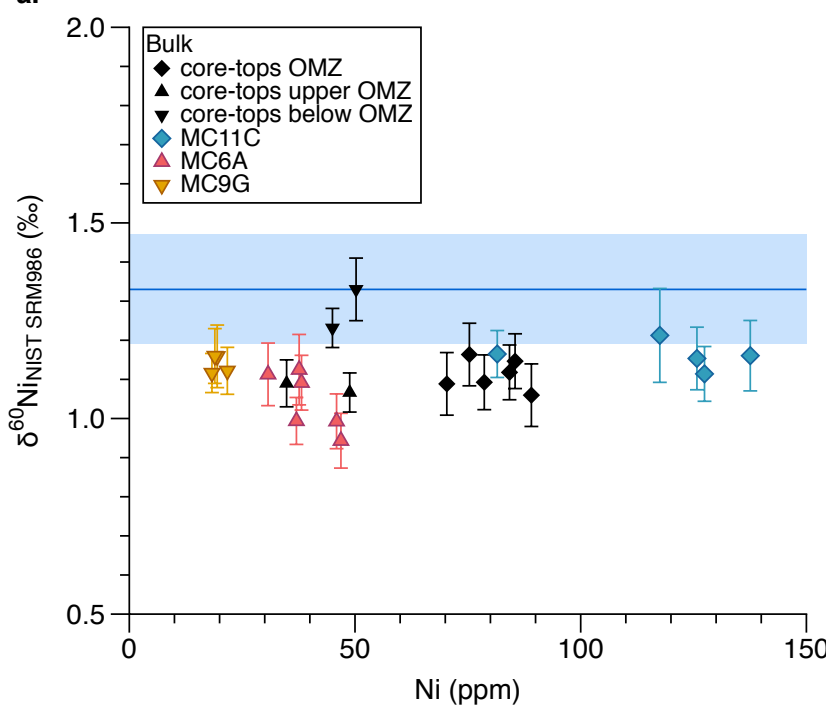

b.

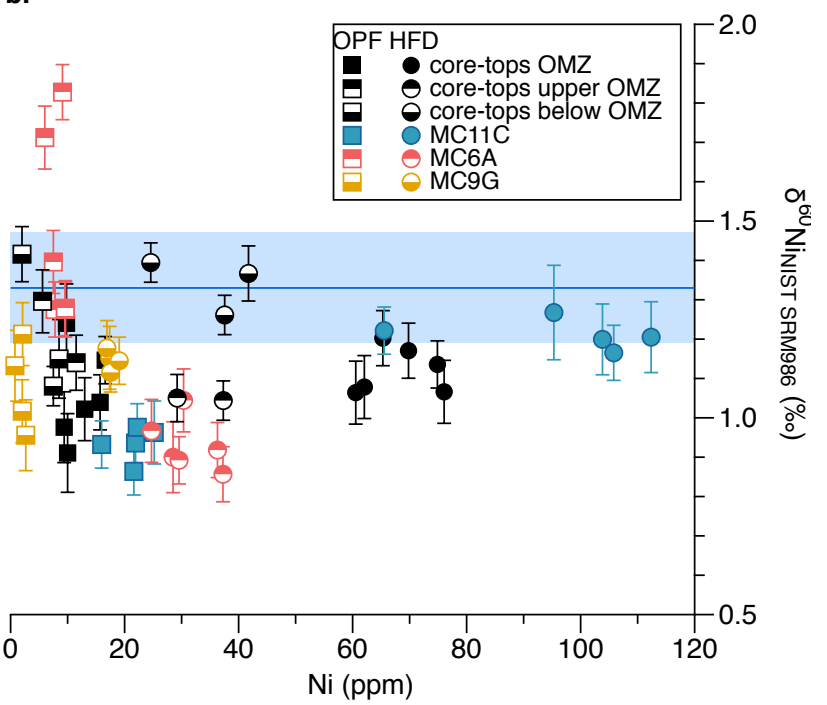

Figure 4: Peru margin Ni abundances and isotope composition calculated for bulk samples (a) and as measured for the respective OPF and HFD fractions of the same samples (b). The blue line and associated band indicate the average and $2 \sigma$ of the Ni isotopic composition of the modern deep ocean (defined by depths greater than $1000 \mathrm{~m}$, references in text). 
a.

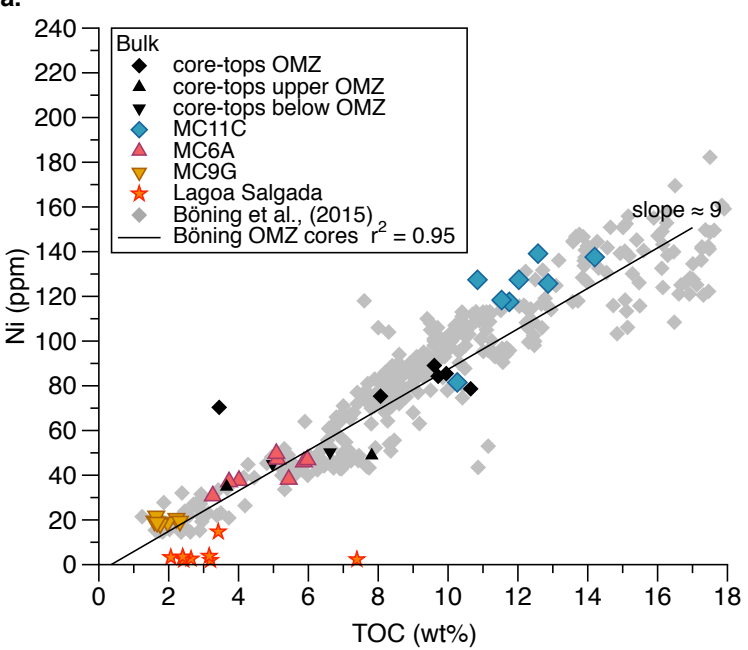

c.

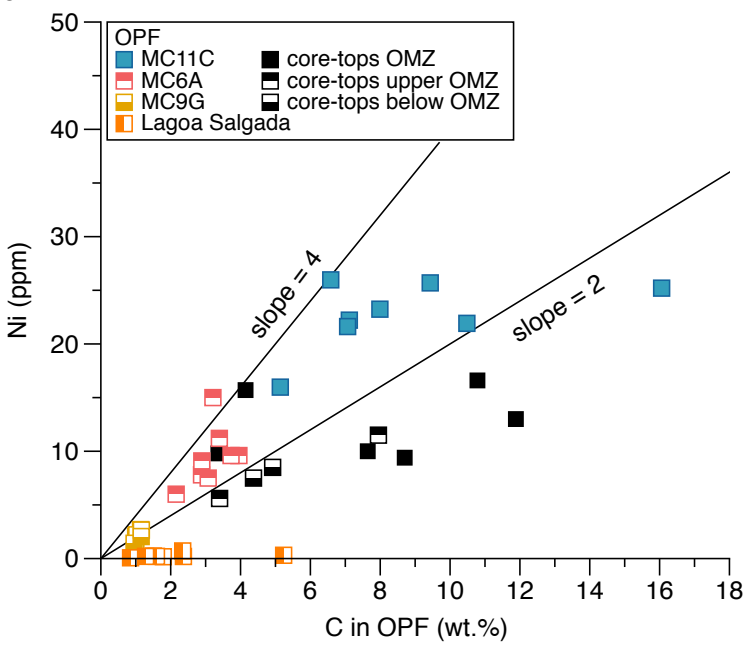

b.

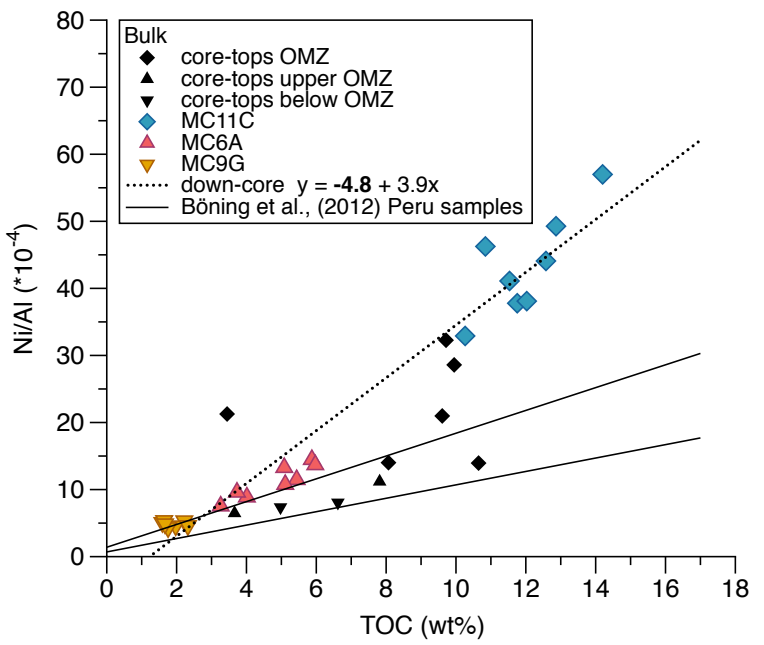

d.

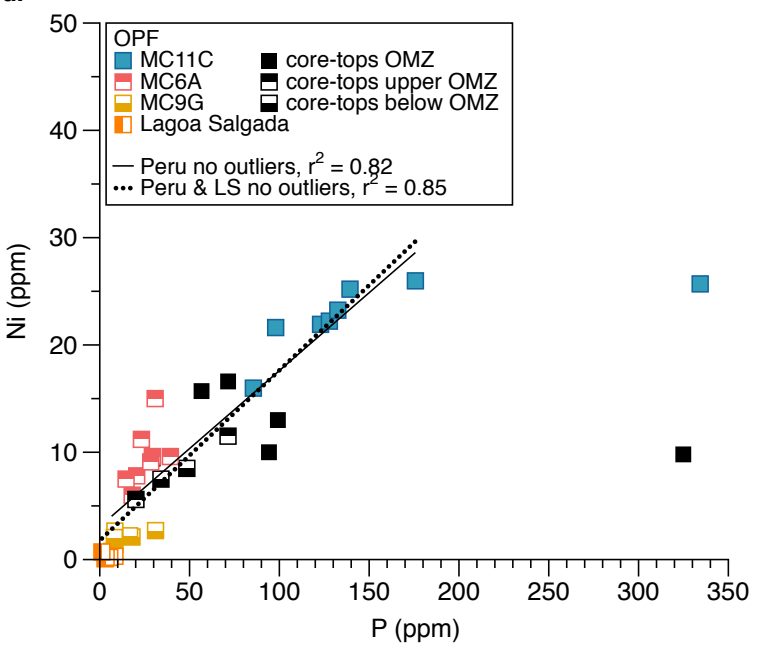

Figure 5: Ni abundances plotted versus TOC for the sediments studied here. (a) Data for Peru Margin bulk sediments, compared to data reported in Böning et al. (2015) for sediments in upwelling regions globally. The strong correlation between Ni abundance and TOC in the OMZ sediments suggests delivery of $\mathrm{Ni}$ to the sediments via organic matter (data in gray from Böning et al., 2015). (b) Ni/Al vs. TOC for the Peru Margin sediments studied here. The Ni organic matter association for Peru margin samples is further supported by (c) the correlation between $\mathrm{Ni}$ abundance in the OPF fraction versus \%orgC in the OPF and (d) the strong correlation between Ni and P abundances in the OPF fraction in all but two of the Peru Margin samples. 


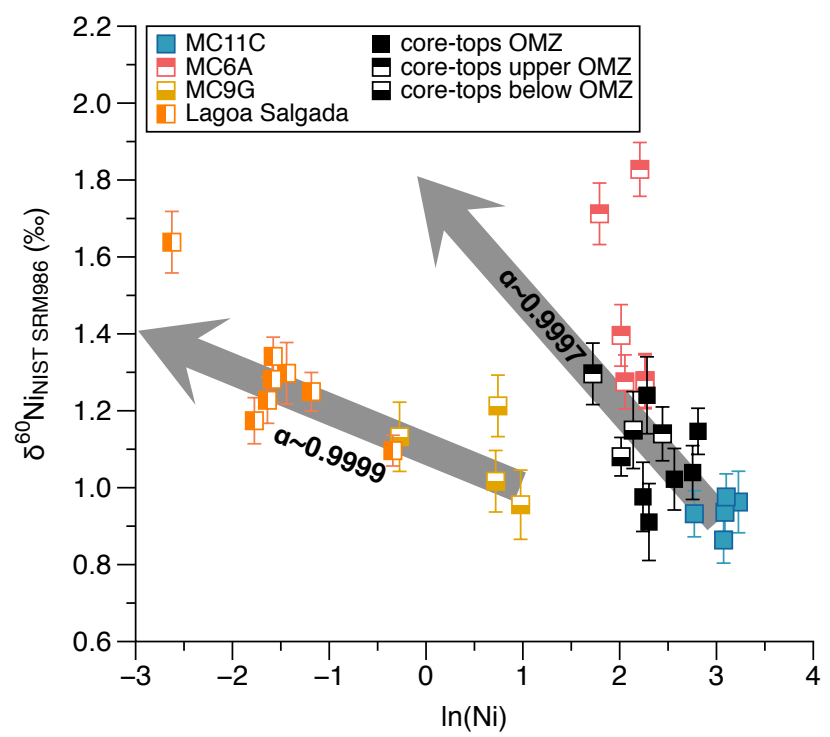

Figure 6: $\delta^{60} \mathrm{Ni}$ vs. $\ln [\mathrm{Ni}]$ in the organic-pyrite fractions (OPF) of Peru Margin and Lagoa Salgada sediments. Most Peru Margin samples for cores within the OMZ, as well as all core-top samples, lie on an array that is consistent with removal of $\mathrm{Ni}$ from a water column with a $\mathrm{Ni}$ isotopic composition close to the deep ocean value. The arrow labeled $\alpha=0.9997$ shows the expected array if the $\mathrm{Ni}$ in the OPF is derived from the photic zone with preferential removal of the light isotope as observed in the water column (Archer et al., 2017; Takano et al., 2017). Most of the data for the Peru Margin samples are consistent with this process. Data for both the Peru Margin core from beneath the OMZ and the Lagoa Salgada may define a fractionation trend representing an alpha that is closer to 1 . 

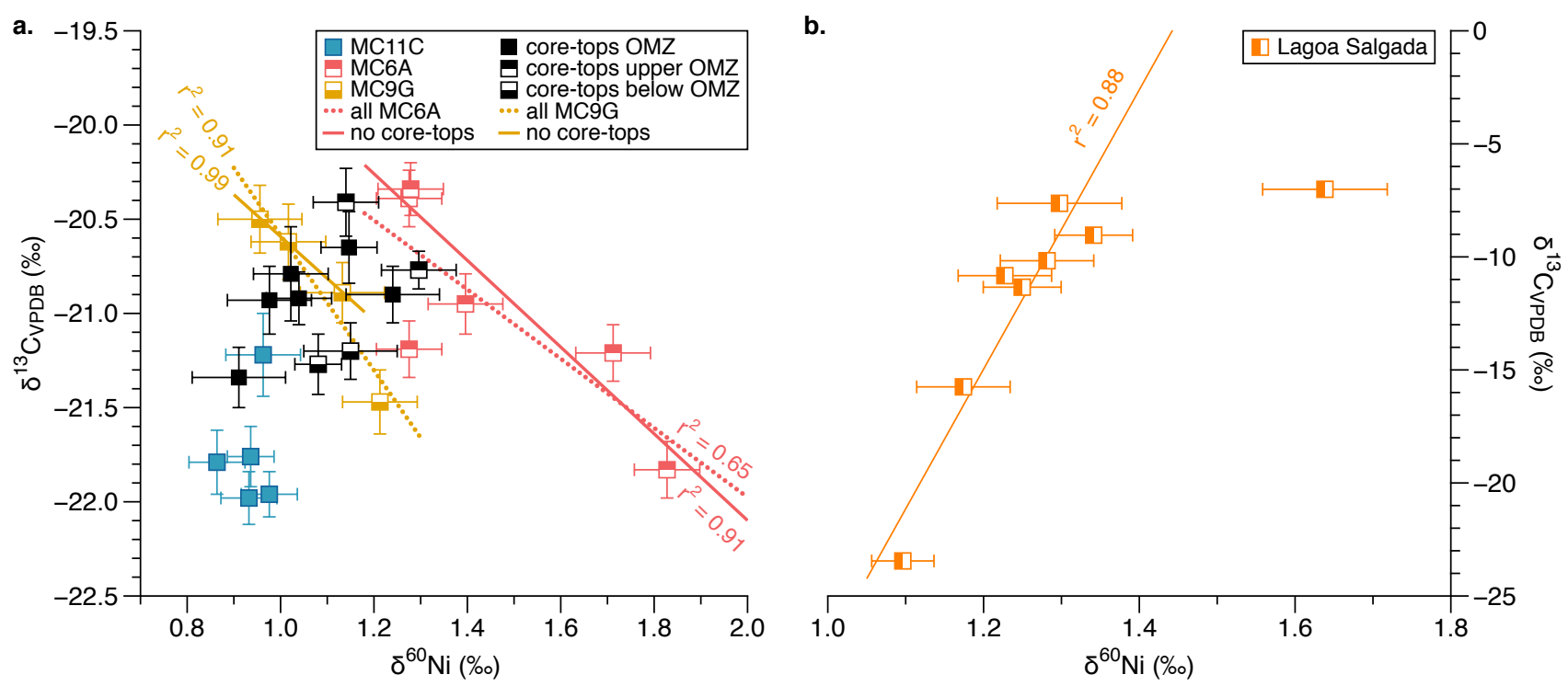

Figure 7: $\delta^{60} \mathrm{Ni}$ vs. $\delta^{13} \mathrm{C}$. Peru margin down-core sediments from the upper edge of and below the OMZ show inverse correlations between $\delta^{60} \mathrm{Ni}$ and $\delta^{13} \mathrm{C}$ of the OPF fraction that appear to be specific to each location. (b) Lagoa Salgada OPF fractions exhibit an opposite (positive) correlation between $\delta^{60} \mathrm{Ni}$ and $\delta^{13} \mathrm{C}$. 


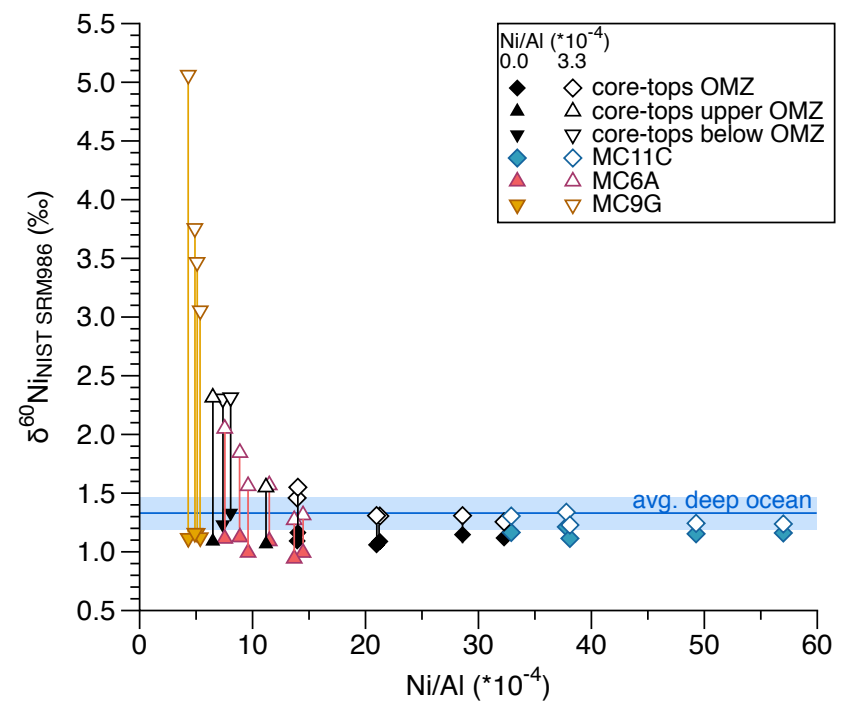

Figure 8: Peru Margin authigenic $\delta^{60} \mathrm{Ni}$ obtained after a correction for detrital Ni, using Ni/Al detrital of 0 (i.e., no correction, filled symbols) and of $3.3^{*} 10^{-4} \mathrm{~g} / \mathrm{g}$ (empty symbols). The bars between the empty and filled symbol of each sample indicate the range along which the $\delta^{60} \mathrm{Ni}_{\text {authigenic }}$ could lie. The blue line and associated band indicate the average and $2 \sigma$ of the $\mathrm{Ni}$ isotopic composition of the modern deep ocean (defined by depths greater than $1000 \mathrm{~m}$, references in text). 


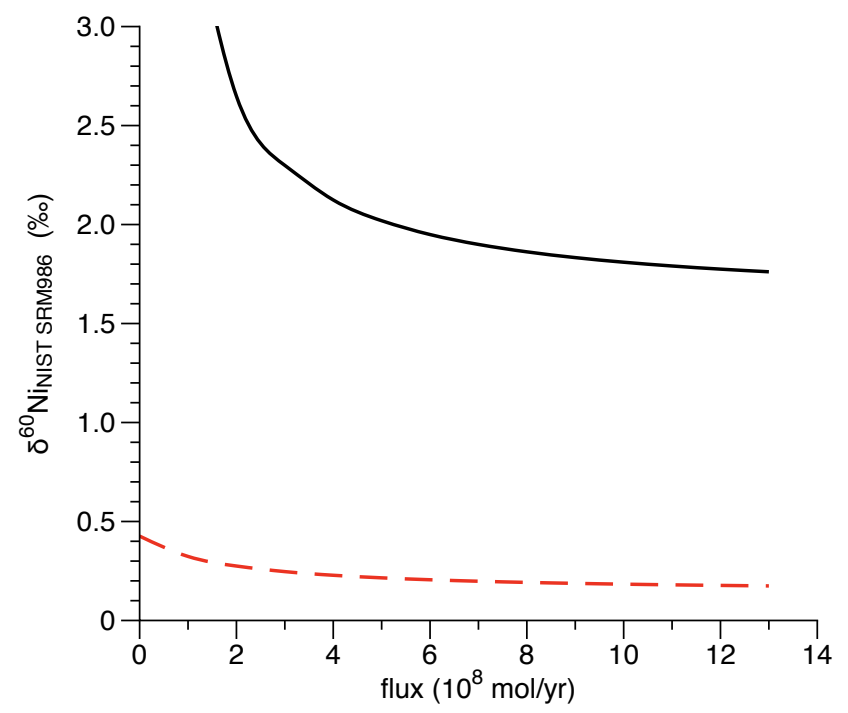

Figure 9: Requirements of two alternative ways to balance the oceanic budget of $\mathrm{Ni}$ and its isotopes. The black curve shows the required isotope composition of a projected missing input versus its size, given a range in size of the Fe-Mn oxide output from that required to balance the currently known inputs (missing input $=$ zero) up to $1.5^{*} 10^{9} \mathrm{~mol} / \mathrm{yr}$ (Cameron and Vance, 2014). The $\delta^{60} \mathrm{Ni}$ of the Fe-Mn oxide output is taken to be the average of data in Gall et al. (2013). The red curve assumes that the required missing input has an isotope composition the same as the upper continental crust, and explores the $\delta^{60} \mathrm{Ni}$ of the effective - e.g. final buried - Fe-Mn oxide output following potential diagenetic modification. Other parameters, for the size and isotopic composition of the better known inputs and outputs, as summarized in Table 3. 
775 Electronic Supplementary Material

776 S1. Peru Margin sample locations and details

Table S1: Peru margin sediment core locations

\begin{tabular}{|c|c|c|c|c|}
\hline core ID & $\begin{array}{l}\text { lat/long } \\
{\left[{ }^{\circ} \mathrm{N} /{ }^{\circ} \mathrm{E}\right]}\end{array}$ & $\begin{array}{c}\text { depth } \\
{[\mathrm{m}]}\end{array}$ & $\begin{array}{c}\text { bottom } \mathrm{O}_{2} \\
{[\mu \mathrm{M}]}\end{array}$ & $\begin{array}{l}\text { location } \\
\text { wrt OMZ }\end{array}$ \\
\hline \multicolumn{5}{|c|}{$R / V$ Seward Johnson 10-92 } \\
\hline BC39 & $-13.509 /-76.927$ & 550 & 10 & within OMZ \\
\hline BC57 & $-13.512 /-76.695$ & 172 & $<10$ & within OMZ \\
\hline BC62 & $-13.499 /-76.959$ & 643 & 10 & below OMZ \\
\hline $\mathrm{BC} 76$ & $-13.502 /-76.983$ & 725 & 15 & below OMZ \\
\hline BC81 & $-13.508 /-76.578$ & 130 & 10 & within OMZ \\
\hline $\mathrm{KC} 83$ & $-13.518 /-76.473$ & 106 & 10 & upper OMZ \\
\hline BC93 & $-12.000 /-77.335$ & 100 & 5 & upper OMZ \\
\hline $\mathrm{BC} 125$ & $-11.998 /-77.807$ & 340 & 5 & within OMZ \\
\hline $\mathrm{KC} 127$ & $-11.996 /-77.790$ & 309 & 5 & within OMZ \\
\hline $\mathrm{BC} 153$ & $-11.062 /-78.073$ & 250 & 5 & within OMZ \\
\hline \multicolumn{5}{|c|}{$R / V$ Knorr 182-9 } \\
\hline MC6A & $-13.250 /-76.500$ & 100 & 2 & upper OMZ \\
\hline $\mathrm{MC} 9 \mathrm{G}$ & $-11.718 /-78.399$ & 1500 & 80 & below OMZ \\
\hline $\mathrm{MC} 11 \mathrm{C}$ & $-11.000 /-78.167$ & 325 & 2 & within OMZ \\
\hline
\end{tabular}


803

\section{S2. Analytical Methods}

\section{S2.1. General analytical procedure}

All procedural steps described in this study were performed in the clean laboratory facilities at the Institute of Geochemistry and Petrology at ETH Zürich. All containers used were trace metal cleaned Savillex PFA labware products and all acids were either of ultrapure grade or twice distilled before use.

The HF-digestible fraction was obtained via a $\mathrm{HF}-\mathrm{HCl}$ digestion of $\sim 1 \mathrm{~g}$ of sediment performed in $60 \mathrm{ml}$ Teflon beakers. Specifically, this involves a $24 \mathrm{hr}$ digestion at $150^{\circ} \mathrm{C}$ in $3 \mathrm{ml}$ concentrated $\mathrm{HF}$ and $2 \mathrm{ml}$ of $7 \mathrm{M} \mathrm{HCl}$ mixture, followed by two steps involving 24hr reflux at $150^{\circ} \mathrm{C}$ with $7 \mathrm{M} \mathrm{HCl}$, evaporating to dryness between each step. $7 \mathrm{M} \mathrm{HCl}$ is then added a final time, again refluxing $24 \mathrm{hr}$ at $150^{\circ} \mathrm{C}$. The resulting $\mathrm{HF}$-dissolvable fraction (HFD) and the residual solid (organic matter and associated pyrite, OPF) were then separated by centrifugation and decanting of the supernatant solution. The residual OPF was brought into solution via high-pressure ashing (HPA-S by Anton Paar) in a 10:1 mixture by volume of $13 \mathrm{M} \mathrm{HNO}_{3}$ and $10 \mathrm{M} \mathrm{HCl}$, subsequent evaporation to dryness, and final dissolution in $1 \mathrm{ml}$ of $0.3 \mathrm{M} \mathrm{HNO}_{3}$.

All OPF and HFD fractions were analyzed for elemental abundances on a ThermoScientific Element $\mathrm{XR}^{\mathrm{TM}}$ inductively-coupled plasma mass spectrometer (ICP-MS) at ETH Zürich. Accuracy and reproducibility were determined by repeat analyses of a commercially available carbonate-enriched shale standard (Green River Shale, SGR-1, United States Geological Survey, USA). For Ni and Al the long-term reproducibility of this standard, assessed over the period during which the data here presented were obtained, is $\pm 8 \%$ and $\pm 7 \%$ (2SD, $\mathrm{n}=40)$, respectively, and the measured concentrations are, for both, $100 \%$ of their certified values.

For isolation and purification of $\mathrm{Ni}$ fractions from other elements and from the sam- 
805 ple matrix, a sample aliquot containing approximately 100ng of Ni was first spiked with $806 \mathrm{a}^{61} \mathrm{Ni}^{-62} \mathrm{Ni}$ double spike and the mixture allowed to equilibrate for up to $24 \mathrm{hr}$. Spiked 807 samples were then passed through an anion exchange column (Bio-Rad macroporous AG 808 MP-1M resin) and a subsequent column filled with Ni-specific DMG resin (Eichrom Tech809 nologies) following the procedure outlined in Cameron and Vance (2014). Oxidation for 8103 -5 days was then necessary to remove Ni-bound DMG. At this point we noted that 811 some samples still contained elevated amounts of Ca relative to Ni. This resulted in an 812 interference at mass $56\left({ }^{40} \mathrm{Ca}^{16} \mathrm{O}\right)$, which we use to monitor a potential ${ }^{58} \mathrm{Fe}$ interference 813 on ${ }^{58} \mathrm{Ni}$ (see below), so that we introduced an additional Nobias-chelate PA1 (Hitachi 814 High Technologies) column prior to the final anion exchange column step described in 815 Cameron and Vance (2014). The additional Nobias-chelate PA1 resin column is a minia816 turized, gravity-driven version of the large flow-through system described by Takano et al. 817 (2013) for processing of seawater samples. The columns, containing the Nobias-chelating 818 PA1 resin, were cleaned with $1 \mathrm{ml} 1 \mathrm{M} \mathrm{HCl}$, and conditioned with $1 \mathrm{ml} \mathrm{MQ} \mathrm{H}_{2} \mathrm{O}$ followed 819 by two passes of $0.5 \mathrm{ml} 30 \mathrm{mM} \mathrm{AcNH}_{4}$ buffer. The sample, following oxidation to remove 820 Ni-bound DMG, is dissolved in a 10:1 mixture of $0.5 \mathrm{M} \mathrm{HCl}$ and $1 \mathrm{M}$ ammonium acetate 821 buffer, with $\mathrm{pH}$ adjusted to $5 \pm 0.5$ by addition of ammonia solution. The matrix is eluted 822 in $0.5 \mathrm{ml} 30 \mathrm{mM}$ AcNH4 buffer, and the Ni fraction is collected in $1 \mathrm{ml}$ of $1 \mathrm{M} \mathrm{HCl}$. A final 823 anion exchange column is used to remove any residual Fe. The total Ni blank for this 824 procedure was 3ng, dominated by the DMG column. A blank correction was applied to 825 all samples assuming a $\delta^{60} \mathrm{Ni}$ for the blank of $0 \%$. For all except one sample, the resulting 826 shift is no greater than analytical uncertainty (for LS30 OPF $\delta^{60} \mathrm{Ni}$ is shifted upwards by $8270.15 \%$ relative to that with no blank correction). Alongside each set of samples passed 828 through the entire column procedure described above, we also process one of two USGS 829 Fe-Mn nodule standards (Nod A1 and Nod P1).

830

831 Isotopic analyses of $\sim 100 \mathrm{ppb}$ of the purified $\mathrm{Ni}$ fractions, dissolved in a solution of $8320.3 \mathrm{M} \mathrm{HNO}_{3}$, were performed using a ThermoFinnigan NeptunePlus multicollector ICPMS 833 at ETH Zürich. The sample introduction system comprised either a CPI PFA nebulizer 
$834(50 \mu \mathrm{l} / \mathrm{min})$ or a Savillex C-Flow PFA nebulizer (35 or $50 \mu \mathrm{l} / \mathrm{min}$ ) connected to an Aridus.

835 A known interference from ${ }^{58} \mathrm{Fe}$ on ${ }^{58} \mathrm{Ni}$ was monitored by measuring ${ }^{56} \mathrm{Fe}$ and applying a 836 correction. Many of the samples in this study had small residual amounts of $\mathrm{Fe}$ in the $\mathrm{Ni}$ 837 fraction, in most cases blank Fe from the small anion column at the end of the chemical 838 separation procedure. An interference-correction for ${ }^{58} \mathrm{Fe}$ on ${ }^{58} \mathrm{Ni}$ was tested by analyzing 839 Fe-doped Ni standard-spike mixtures. The results of this test are shown below (Fig. S1) 840 for a range of measured 56/58 signal ratios up to values in excess of 20. Ratios in the 841 samples reported here were almost all $<0.3$, but six Lagoa Salgada OPF samples were in 842 the range $0.3-0.7$ and one was 2.6. Correction for mass discrimination was done using the 843 double spike approach, as detailed in Cameron and Vance (2014).

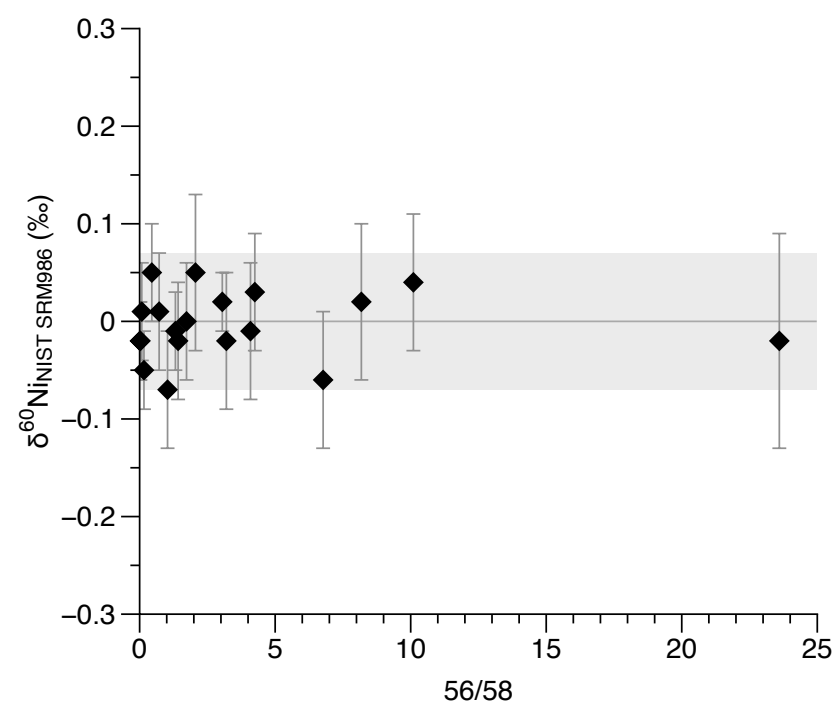

Figure S1: $\delta^{60} \mathrm{Ni}$ for Fe-doped spike-NIST standard mixtures (expected result $=0 \%$, average and 2SD of all data $=0.00 \pm 0.07 \%$, gray band). These data were obtained in two analytical sessions. To verify that the correction is robust over long periods, all subsequent sessions contained a measurement of an Fe-doped standard-spike mixture with a $56 / 58$ ratio of $2-3$. That the measured 56 signal is ${ }^{56} \mathrm{Fe}$ is verified through measurement of the $56 / 57$ ratio. The required ${ }^{58} \mathrm{Fe} /{ }^{56} \mathrm{Fe}$ ratio for the correction to be successful for standards was 0.003087 and a mass bias was applied to this ratio using the measured versus mass-bias corrected ${ }^{60} \mathrm{Ni} /{ }^{58} \mathrm{Ni}$ ratio for pure NIST standards measured at the start of each analytical session. 
846 The internal error is determined by propagation of the uncertainties obtained from 847 the NeptunePlus analysis through the double spike algebra. The long-term external re848 producibility was determined by repeat measurements of two secondary standards, USGS 849 NodA1 and Nod P1. Analyses performed during the period when the data presented here 850 were obtained yielded $\delta^{60} \mathrm{Ni}=1.04 \pm 0.07 \%(\mathrm{n}=120)$ and $\delta^{60} \mathrm{Ni}=0.34 \pm 0.08 \%(\mathrm{n}=99)$, 851 respectively. In all tables and diagrams, these reproducibilities are taken to be the real 852 uncertainties unless, as in rare cases when analytical signals were small, the internal un853 certainty was greater, in which case the latter is used.

854

855 Freeze-dried sediment samples and the extracted OPFs were analyzed for total organic 856 carbon (TOC) and for their $\delta^{13} \mathrm{C}$ composition using a ThermoFisher Flash-EA 1112 via a 857 Conflo IV interface to a ThermoFisher Delta V isotope ratio mass spectrometer (IRMS), 858 with a long-term reproducibility of $5-15 \%$. The freeze-dried bulk sediments were first 859 decarbonated with $6 \mathrm{M} \mathrm{HCl}$ for $24 \mathrm{hr}$, rinsed with $\mathrm{MilliQ}$ and then dried at $50^{\circ} \mathrm{C}$ for at 860 least $48 \mathrm{hr}$. All samples were combusted in an oxidation column at $1020^{\circ} \mathrm{C}$. Combustion 861 gases were passed through a reduction column set at $650^{\circ} \mathrm{C}$, the resulting $\mathrm{N}_{2}$ and $\mathrm{CO}_{2}$ 862 gases were separated chromatographically and transferred to the IRMS via an open split 863 for on-line isotope measurements.

\section{S2.2. Tests of digestion approach}

865 We examined the OPF fractions using SEM (e.g., Fig. S2). The dominant visible 866 fraction is organic material as confirmed by semi-quantitative in situ EDAX analyses, 867 but there are also, clearly, bright cuboid grains that are identified as sulphide. At this 868 stage we do not know the Ni mass balance between these two phases.

870 As summarized briefly in section 3.1 of the main paper, we also investigated potential 871 method-induced isotope fractionation by subjecting three sub-samples of a single core-top 872 (BC81) to one, two, and three digestions. The OPF was obtained and analyzed only at 873 the end of these sets of HF extractions. The approach is shown schematically in Figure 
874 S3. Each of the three subsamples A, B, and C were processed in duplicate. The resulting $875 \mathrm{Ni}$ concentration and isotope composition for each HFD and OPF fraction are reported 876 in Table S1. In all cases most of the nickel in the HFD fraction is recovered during the 877 first digestion, with only minor contributions from a second and third digestion (Fig. S4). 878 The nickel isotope composition of the HFD fractions are within analytical uncertainty 879 of each other (Fig. S5) except for the very small amount of Ni in fraction HFD3 from 880 sub-sample C, a substantial portion of which is certainly blank. The Ni concentrations 881 and isotopic compositions of the three OPF fractions are also practically identical within 882 analytical uncertainties (Fig S4, 5). After this test, all samples processed in this study 883 were digested only once. This experiment suggests that a single extraction accesses al884 most all the HF-extractable $\mathrm{Ni}$, and that the OPF is not significantly affected by the HF 885 extraction - e.g., there is no difference in either concentration or $\delta^{60} \mathrm{Ni}$ after one, two or 886 three HF extractions.

887

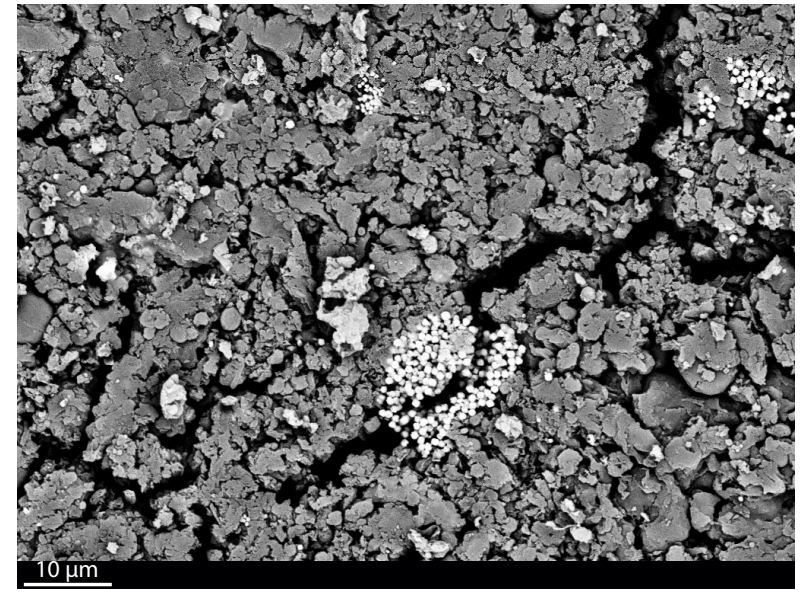

Figure S2 


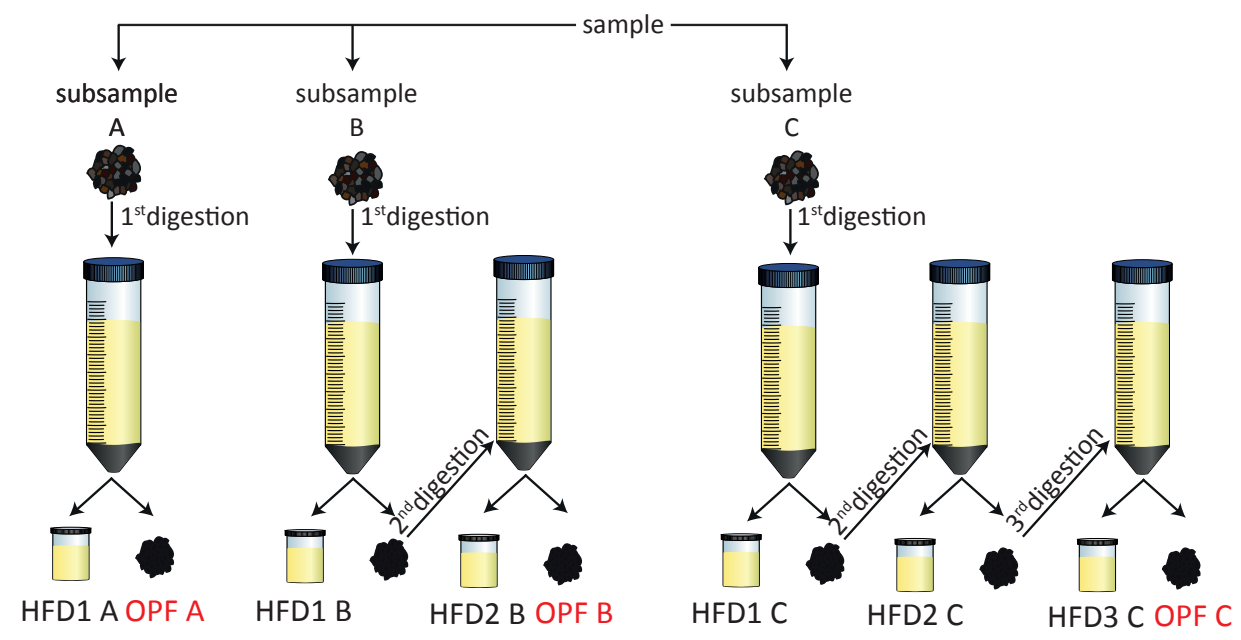

Figure S3: Schematic representation of the method validation experiment. All subsample digestions were repeated in complete duplicate but only one of each is shown here.

Table S2: Results of method validation experiments

\begin{tabular}{|c|c|c|c|c|c|c|c|c|c|}
\hline \multirow[b]{2}{*}{ sample } & \multicolumn{3}{|c|}{ duplicate 1} & \multicolumn{3}{|c|}{ duplicate 2} & \multicolumn{3}{|c|}{ average } \\
\hline & $\begin{array}{c}\text { Ni Elem }{ }^{1} \\
{[\mathrm{ppm}]}\end{array}$ & $\begin{array}{c}\delta^{60} \mathrm{Ni} \\
{[\% 0]}\end{array}$ & $2 \sigma$ & $\begin{array}{c}\text { Ni Elem }{ }^{1} \\
{[\mathrm{ppm}]}\end{array}$ & $\begin{array}{c}\delta^{60} \mathrm{Ni} \\
{[\% 0]}\end{array}$ & $2 \sigma$ & $\begin{array}{c}\text { Ni Elem }{ }^{1} \\
{[\mathrm{ppm}]}\end{array}$ & $\begin{array}{c}\delta^{60} \mathrm{Ni} \\
{[\% 0]}\end{array}$ & $2 \sigma^{2}$ \\
\hline BC81A OPF & 12 & 1.21 & 0.06 & 16 & 1.16 & 0.06 & 14 & 1.19 & 0.07 \\
\hline BC81A HFD1 & 104 & 1.33 & 0.05 & 119 & 1.28 & 0.03 & 111 & 1.30 & 0.07 \\
\hline BC81B OPF & 12 & 1.04 & 0.04 & 13 & 1.06 & 0.03 & 12 & 1.05 & 0.07 \\
\hline BC81B HFD1 & 119 & 1.31 & 0.04 & 117 & 1.23 & 0.04 & 118 & 1.27 & 0.07 \\
\hline BC81B HFD2 & 10 & 1.21 & 0.04 & 7.5 & 1.31 & 0.07 & 8.8 & 1.26 & 0.07 \\
\hline BC81C OPF & 12 & 1.03 & 0.03 & 8.7 & 1.00 & 0.02 & 10 & 1.01 & 0.07 \\
\hline BC81C HFD1 & $67^{*}$ & 1.26 & 0.04 & 110 & 1.31 & 0.04 & 110 & 1.28 & 0.07 \\
\hline BC81C HFD2 & 8.9 & 1.19 & 0.07 & 14 & 1.18 & 0.05 & 12 & 1.18 & 0.07 \\
\hline BC81C HFD3 & 2.7 & 1.02 & 0.04 & 2.9 & $\mathrm{n} / \mathrm{a}$ & $\mathrm{n} / \mathrm{a}$ & 2.8 & 1.02 & 0.07 \\
\hline
\end{tabular}

${ }^{1}$ Concentrations obtained via ElementXR analysis.

${ }^{2}$ All duplicate analyses agree to a level that is consistent with the long-term reproducibility and this is used as the uncertainty here and in Fig. S5.

* Leakage of solution from beaker, hence this concentration was not used in the calculation of the average. 


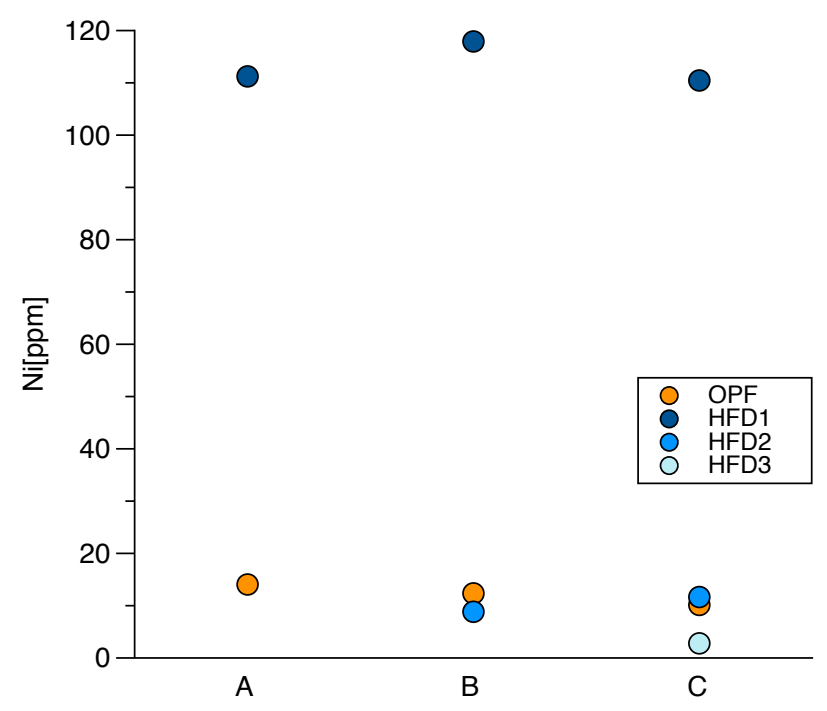

Figure S4: Ni concentrations in the OPF and HFDs for each of the three method validation steps. Note that most of the $\mathrm{Ni}$ in the HFD fraction is recovered with the first digestion, with contributions from further digestion being minor.

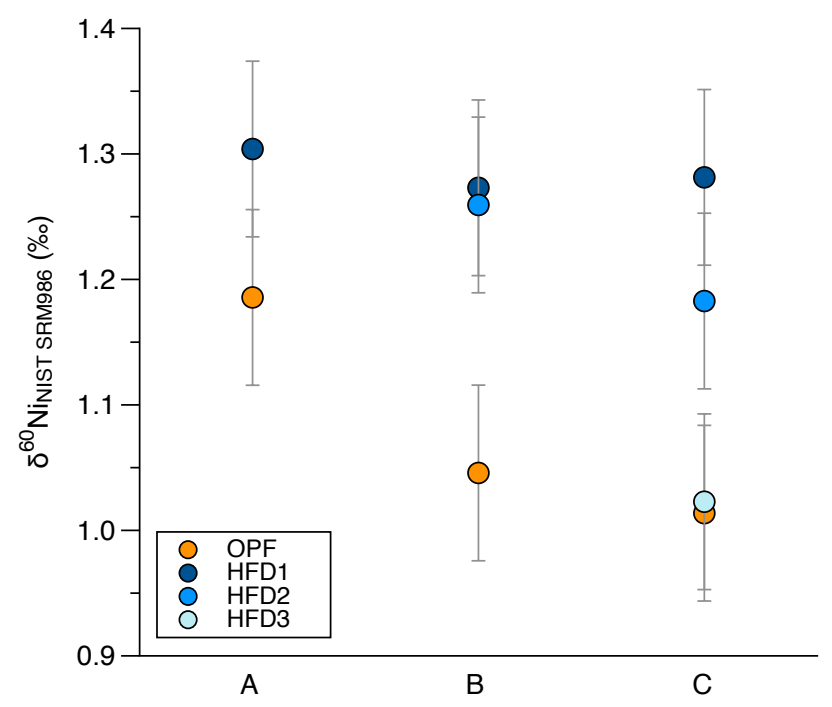

Figure S5: Ni isotope composition of the OPF and HFDs for each of the three method validation steps. Error bars indicate the long-term external reproducibility $(2 \sigma)$.

888 A separate issue concerns the presence of small amounts of residual $\mathrm{Al}$ in the $\mathrm{OPF}$, and 889 the degree to which the OPF may contain residual undigested clays. Table S3 presents 
890 further data for the chemistry of the OPF. Elemental ratios do not correspond to those of 891 clays. They do correspond to those of fluoride salts that are commonly residual after HF 892 digestion of silicates (e.g., Croudace, 1980). Powder XRD analyses on two OPF fractions 893 (Figure S6) confirm the presence of fluorides in the OPF, hence likely explaining the 894 presence of $\mathrm{Al}$ in the $\mathrm{OPF}$. 
Table S3: Elemental abundance and ratios to $\mathrm{Al}$ of $\mathrm{Na}, \mathrm{Mg}$, $\mathrm{Ca}$ in $\mathrm{OPF}$

\begin{tabular}{|c|c|c|c|c|c|c|c|}
\hline sample & $\begin{array}{c}\mathrm{Na} \\
\text { (wt.\%) }\end{array}$ & $\begin{array}{c}\mathrm{Mg} \\
(\mathrm{ppm})\end{array}$ & $\begin{array}{c}\mathrm{Ca} \\
(\mathrm{ppm})\end{array}$ & $\begin{array}{c}\mathrm{Al} \\
\text { (wt.\%) }\end{array}$ & $\mathrm{Na} / \mathrm{Al}$ & $\mathrm{Mg} / \mathrm{Al}$ & $\mathrm{Ca} / \mathrm{Al}$ \\
\hline BC39 & 1.4 & 2901 & 6223 & 1.0 & 1.4 & 0.28 & 0.60 \\
\hline BC57 & 3.9 & 3112 & 2197 & 0.7 & 5.3 & 0.42 & 0.30 \\
\hline BC62 & 1.8 & 2882 & 4555 & 0.9 & 2.0 & 0.32 & 0.50 \\
\hline $\mathrm{BC} 76$ & 3.0 & 5982 & 9089 & 1.5 & 2.1 & 0.41 & 0.62 \\
\hline BC81 & 4.2 & 3658 & 1043 & 1.1 & 3.7 & 0.32 & 0.09 \\
\hline $\mathrm{KC} 83$ & 5.8 & 4663 & 1203 & 1.3 & 4.3 & 0.35 & 0.09 \\
\hline BC93 & 3.9 & 2053 & 812 & 0.3 & 12 & 0.65 & 0.26 \\
\hline BC 125 & 4.3 & 2561 & 2103 & 0.7 & 6.3 & 0.38 & 0.31 \\
\hline $\mathrm{KC} 127$ & 4.5 & 2490 & 2119 & 0.4 & 11 & 0.61 & 0.52 \\
\hline BC 153 & 3.1 & 1314 & 1762 & 0.1 & 22 & 0.93 & 1.2 \\
\hline MC6A1 & 3.2 & 3717 & 1179 & 0.7 & 4.7 & 0.54 & 0.17 \\
\hline MC6A6 & 2.8 & 4548 & 923 & 0.8 & 3.4 & 0.55 & 0.11 \\
\hline MC6A14 & 2.5 & 4394 & 1166 & 0.9 & 2.9 & 0.52 & 0.14 \\
\hline MC6A16 & 2.3 & 5149 & 1785 & 1.1 & 2.1 & 0.47 & 0.16 \\
\hline MC6A22 & 1.0 & 3994 & 1159 & 0.9 & 1.2 & 0.47 & 0.14 \\
\hline MC6A26 & 1.2 & 4423 & 1783 & 1.2 & 1.1 & 0.38 & 0.15 \\
\hline MC6A37 & 1.1 & 2357 & 558 & 0.5 & 2.2 & 0.46 & 0.11 \\
\hline MC6A 4446 & 1.1 & 3066 & 1033 & 0.8 & 1.2 & 0.36 & 0.12 \\
\hline MC9G1 & 0.6 & 3042 & 7643 & 0.4 & 1.5 & 0.74 & 1.9 \\
\hline MC9G3 & 0.6 & 2937 & 9162 & 0.4 & 1.6 & 0.79 & 2.5 \\
\hline MC9G5 & 0.5 & 3257 & 8020 & 0.4 & 1.1 & 0.80 & 2.0 \\
\hline MC9G7 & 0.2 & 1215 & 2491 & 0.2 & 1.0 & 0.53 & 1.1 \\
\hline MC9G9 & 0.5 & 1406 & 7188 & 0.4 & 1.4 & 0.39 & 2.0 \\
\hline MC9G11 & 0.5 & 2731 & 9244 & 0.3 & 1.4 & 0.78 & 2.7 \\
\hline MC9G13 & 0.4 & 3128 & 7729 & 0.4 & 1.0 & 0.80 & 2.0 \\
\hline $\mathrm{MC} 11 \mathrm{C} 4$ & 2.7 & 4696 & 1753 & 0.7 & 3.7 & 0.64 & 0.24 \\
\hline $\mathrm{MC} 11 \mathrm{C} 8$ & 1.7 & 4239 & 2228 & 0.7 & 2.4 & 0.59 & 0.31 \\
\hline $\mathrm{MC} 11 \mathrm{C} 17$ & 1.3 & 5162 & 2093 & 0.9 & 1.4 & 0.55 & 0.22 \\
\hline $\mathrm{MC} 11 \mathrm{C} 23$ & 1.3 & 4516 & 2632 & 0.8 & 1.7 & 0.56 & 0.33 \\
\hline $\mathrm{MC} 11 \mathrm{C} 28$ & 0.6 & 3647 & 1721 & 0.7 & 0.8 & 0.52 & 0.24 \\
\hline MC11C35 & 0.2 & 1716 & 1345 & 0.3 & 0.8 & 0.54 & 0.42 \\
\hline MC11C37 & 0.7 & 3902 & 1827 & 0.9 & 0.7 & 0.44 & 0.21 \\
\hline $\mathrm{MC} 11 \mathrm{C} 4648$ & 0.7 & 4737 & 12823 & 1.0 & 0.7 & 0.45 & 1.2 \\
\hline LS14 & 0.8 & 209 & 1526 & 0.04 & 23 & 0.59 & 4.3 \\
\hline LS20 & 0.8 & 852 & 1302 & 0.1 & 7.3 & 0.82 & 1.3 \\
\hline $\mathrm{LS} 25$ & 1.0 & 1771 & 3050 & 0.2 & 6.3 & 1.1 & 1.9 \\
\hline LS30 & 0.3 & 1893 & 4949 & 0.2 & 1.3 & 0.86 & 2.3 \\
\hline LS35 & 0.4 & 4110 & 5163 & 0.4 & 1.1 & 1.1 & 1.4 \\
\hline LS40 & 0.6 & 4274 & 6112 & 0.4 & 1.4 & 1.0 & 1.5 \\
\hline LS45 & 0.3 & 1053 & 1288 & 0.1 & 2.7 & 0.93 & 1.1 \\
\hline LS65 & 0.6 & 6964 & 20390 & 1.1 & 0.5 & 0.62 & 1.8 \\
\hline
\end{tabular}



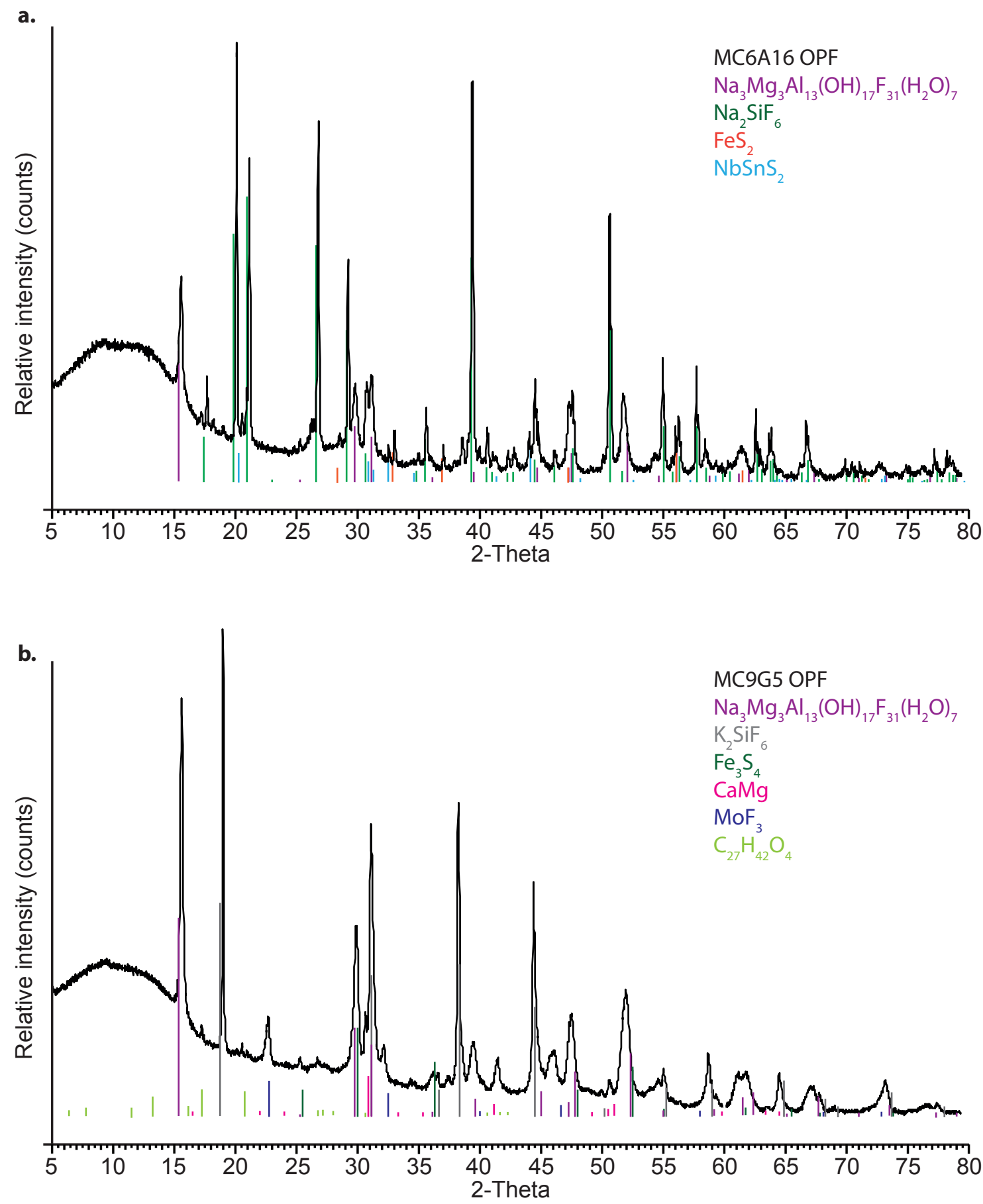

Figure S6: Powder XRD profiles for two OPF fractions (samples MC6A16 OPF and MC9G5 OPF). 
As stated in the main text, the impact of hydrothermal processes on the oceanic 897 budget has not thus far been quantified - whether they represent an input, an output, 898 what the isotopic effects associated with them are. Water column data in the vicinity of 899 the mid-Atlantic Ridge (Fig. S7), that clearly highlight a source of Fe from the ridge, 900 do not show any similarly anomalous Ni concentrations. Indeed, Ni concentrations are, if 901 anything, lightly lower in the Fe plume suggesting removal of $\mathrm{Ni}$, possibly by scavenging 902 to Fe-rich particulates.
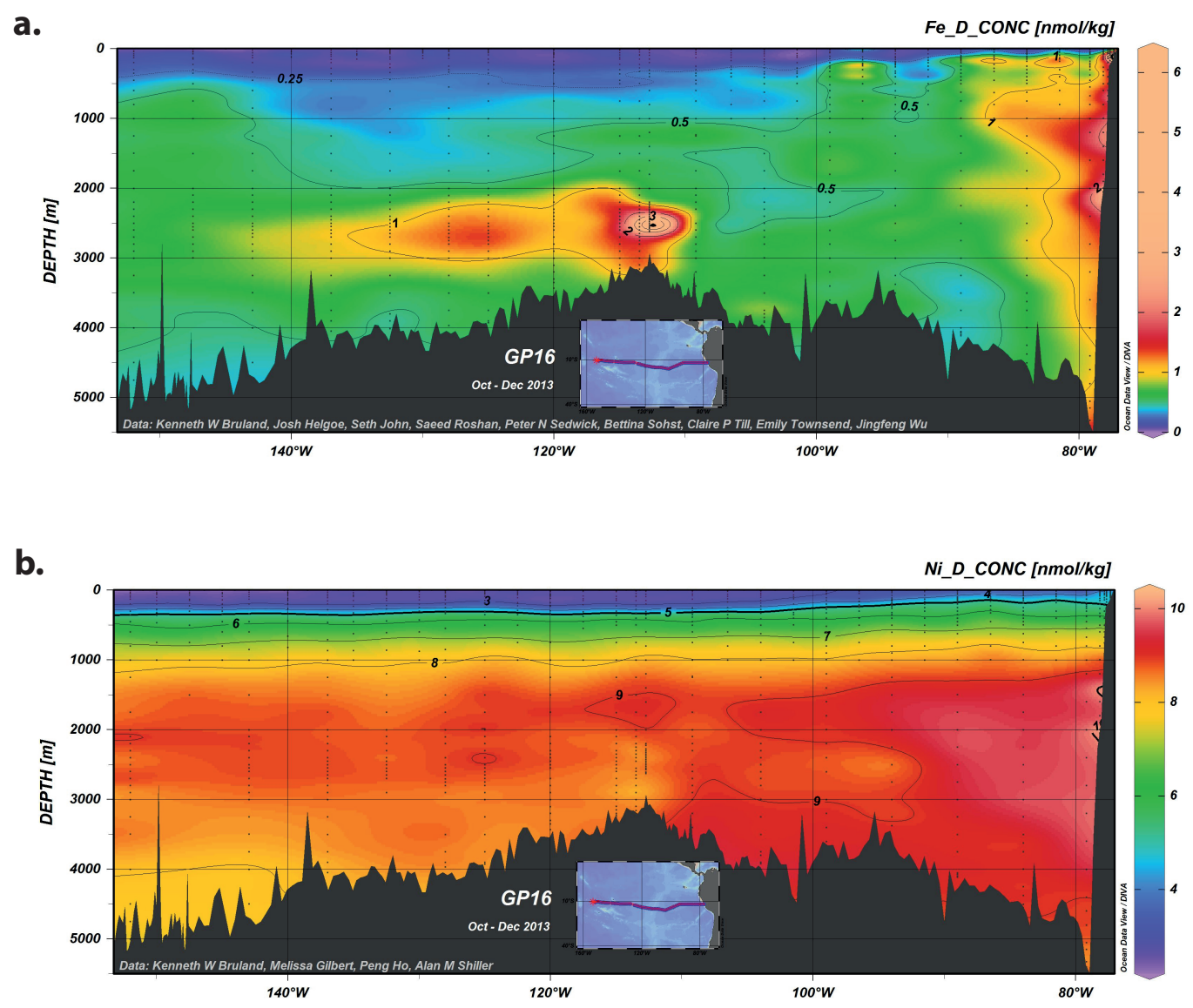

Figure S7: Comparison of dissolved Fe (a) and dissolved Ni (b) concentrations along the GEOTRACES transect GP16 that crosses the Mid-Atlantic Ridge. Plots from the eGEOTRACES Electronic Atlas based on data from the IDP2017 (Schlitzer, 2017). 
903 References

904 Cameron, V., Vance, D., 2014. Heavy nickel isotope compositions in rivers and the oceans. 905 Geochimica et Cosmochimica Acta 128, 195-211.

906 Croudace, I. W., Jan. 1980. A possible error source in silicate wet-chemistry caused by 907 insoluble fluorides. Chemical Geology 31, 153-155.

908 Schlitzer, R., 2017. eGEOTRACES - Electronic Atlas of GEOTRACES Sections and 909 Animated 3d Scenes. http://www.egeotraces.org.

910 Takano, S., Tanimizu, M., Hirata, T., Sohrin, Y., 2013. Determination of isotopic composi911 tion of dissolved copper in seawater by multi-collector inductively coupled plasma mass 912 spectrometry after pre-concentration using an ethylenediaminetriacetic acid chelating 913 resin. Analytica Chimica Acta 784, 33-41. 